\title{
Copepod Abundance and Diversity from Offshore Region of Tuticorin, South East Coast of India
}

\author{
M. Kavitha ${ }^{1^{*}}$, P. Padmavathy ${ }^{2}$, A. Srinivasan ${ }^{2}$, P. Jawahar ${ }^{2}$, \\ L. Ranjith ${ }^{1}$ and D. Linga Prabu ${ }^{1}$ \\ ${ }^{1}$ Tuticorin Research Centre of ICAR-Central Marine Fisheries Research Institute, Tuticorin, \\ Tamil Nadu-628001, India \\ ${ }^{2}$ Fisheries College and Research Institute, Tuticorin, Tamil Nadu-628008, India \\ *Corresponding author
}

\begin{tabular}{|c|}
\hline Keywords \\
\hline $\begin{array}{l}\text { Copepod, Offshore, } \\
\text { species richness, Species } \\
\text { evenness, Species } \\
\text { diversity, Gulf of Mannar }\end{array}$ \\
\hline Article Info \\
\hline $\begin{array}{l}\text { Accepted: } \\
23 \text { March } 2018 \\
\text { Available Online: } \\
10 \text { April } 2018\end{array}$ \\
\hline
\end{tabular}

\section{A B S T R A C T}

A detailed study had been carried out on species abundance, biomass and composition of copepod in four different offshore stations namely, Station I: Vembar, II: Keelavaipar, III: Punnaikayal and IV: Thiruchendhur in Gulf of Mannar region from October 2011 to April 2012. A total of 56 copepod species belongs to 20 families under 4 orders have been encountered during the period. The percentage composition of different groups of copepod species was composed of Calanoida (35 numbers) $62.5 \%$, Cyclopoida (4 numbers) $7.14 \%$, Harpacticoida (8 numbers) $14.3 \%$ and Poecilostomatoida (9 numbers) $16.1 \%$. The percentage of biomass composition of different groups of copepods during the study was in the order of Calanoida 38.99\%, Harpacticoida 32.56\%, Cyclopoida $15.22 \%$ and Poecilostomatoida $13.23 \%$. In the case of species composition, Euterpina acutifrons (28.61\%) was the most abundant species followed by Acrocalanus gracilis $(17.68 \%)$, Corycaeus crassiusculus (12.33\%), Oithona brevicornis (12.03\%) and Temora turbinata $(4.25 \%)$ were the other dominant species in observation. The copepod density in different stations were in the range of 8600-39900, 3900-64600, 3800-24800 and 5000-22500 numbers $\mathrm{m}^{-3}$ at station I, II, II and IV respectively. The lowest biomass of copepod was observed at station III and highest biomass was found at station II. The copepod species richness ranged from 0.48 to 2.72 and species diversity was in the range of 0.87 to 1.98 in the study areas. Species evenness was varied from $0.24-0.51$ during the observation period.

\section{Introduction}

Zooplankton plays an important role in the marine environment as they form a main link between primary producers (phytoplankton) and higher trophic levels (Raymont, 1980; Timofeev, 2000). The zooplankton biomass can increase the fishery productivity because they chiefly consume the phytoplankton and form the vital food source for members of higher trophic levels. Marine zooplankton comprises a wide variety of different organisms with something around ten thousands species of meroplankton which includes tiny flagellates to giant jellyfish. Planktonic copepods are major group of 
zooplankton in terms of biomass, abundance and species number in marine pelagic ecosystems (de Puelles et al., 2003; Leandro et al., 2007). Copepods are most vital secondary producers in coastal and marine ecosystems which lay out an essential link between phytoplankton, micro-zooplankton and higher tropic levels including fish (Beyst et al., 2001; Sherr and Sherr, 2009). Among the variety of zooplankton copepods are extensively distributed throughout the World Ocean and represents $80 \%$ of total zooplankton biomass in marine environment (Sampey et al., 2007). Copepods were the dominant taxa similar from west coast (Padmavati and Goswami, 1996) and east coast of India (Mishra and Panigrahy, 1999; Sahu et al., 2010).

Gulf of Mannar is one of the utmost biologically diverse coastal regions in the planet earth that situated in the southeastern coast of India that covers approximately an area of $10,500 \mathrm{~km}^{2}$ along $8^{\circ} 35^{\prime} \mathrm{N}-9^{\circ} 25^{\prime} \mathrm{N}$ latitude and $78^{\circ} 08^{\prime} \mathrm{E}-79^{\circ} 30^{\prime} \mathrm{E}$ longitude spreading from Rameswaram in the north to Tuticorin in the south.

The Gulf of Mannar has been declared as a Biosphere Reserve by the Government of India to protect and conserve its unique, rich biodiversity. According to GOMMBRE (1997), about 3600 species of flora and fauna were known to present in this area in the past. In this biodiversity rich region, there are 126 species of phytoplankton (Kannan et al., 1998) and about 360 species of zooplankton (CMFRI, 1998) have been recorded. Copepods are one of the most broadly studied categories of marine zooplankton especially on the species composition and seasonal distribution in the Indian coastal waters (Sewell, 1929a; Krishnaswamy, 1950, 1953; Pillay, 1971; Madhupratap, 1979; Goswami, 1982; Sarkar et al., 1986; Mishra and Panigrahy, 1996; Padmavathi and Goswami, 1996; Ramaiah and
Nair, 1997; Madhupratap, 1999; Santhanam and Perumal, 2003, 2005; Fernandes and Ramaiah, 2009; Sivaleela and Venkataraman, 2014). There are about 210 numbers of described families, 2,280 genera and more than 14,000 species of copepods recorded in the world. From the earlier studies and reports about 540 numbers of copepod species were documented in Indian waters (Venkataraman, 2012). Few studies have been described on zooplankton and copepod community in Gulf of Mannar region (Jagadeesan et al., 2013; Sewell, 1914; $\quad$ Prasad, 1954; Ummerkutty, 1961, 1965, 1967 a, b; Prabu et al., 2015; Sugumaran, 2016). Detailed study on the abundance, diversity, distribution and biomass of offshore copepods of Gulf of Mannar is scarce. Hence, the present study aims to learn the copepod abundance, biomass and composition of offshore region of Gulf of Mannar.

\section{Materials and Methods}

During the study period the zooplankton samples were collected in four stations of selected fishing grounds of Gulf of Mannar from October 2011 to April 2012. Locations of sampling stations were Keelavaipar ( $8^{\circ} 51^{\prime}$ $\mathrm{N}-8^{\circ} 55^{\prime} \mathrm{N}$ lat. and $78^{\circ} 15^{\prime} \mathrm{E}-78^{\circ} 23^{\prime} \mathrm{E}$ long.), Punnakayal $\left(8^{\circ} 37^{\prime} \mathrm{N}-8^{\circ} 38^{\prime} \mathrm{N}\right.$ lat. and $78^{\circ} 11^{\prime}$ $\mathrm{E}-78^{\circ} 17^{\prime} \mathrm{E}$ long.), Vembar $\left(8^{\circ} 01^{\prime} \mathrm{N}\right.$ $8^{\circ} 59^{\prime} \mathrm{N}$ lat. and $78^{\circ} 19^{\prime} \mathrm{E}-78^{\circ} 30^{\prime} \mathrm{E}$ long.) and Thiruchendhur $\left(8^{\circ} 27^{\prime} \mathrm{N}-8^{\circ} 32^{\prime} \mathrm{N}\right.$ lat. and $78^{\circ} 07^{\prime} \mathrm{E}-78^{\circ} 17^{\circ} \mathrm{E}$ long.).

The copepod samples were collected from the four stations at a monthly interval from the surface waters by horizontal towing of a zooplankton net with $35 \mathrm{~cm}$ diameter wide mouth made up of bolting silk (No. 10, mesh size $158 \mathrm{~mm}$ ). The collected plankton samples were preserved in 5\% buffered formalin and used for qualitative analysis (Parsons, 1984). The copepod species were identified by using Kasturirangan (1963), Santhanam and 
Srinivasan (1994) and Sewell (1929b). The copepods were identified to genus/species level using phase contrast microscope. For the quantitative analysis of zooplankton $1000 \mathrm{~L}$ of sea water was filtered through same size plankton net. The collected plankton sample was made up to known volume and a subsample of $1 \mathrm{~mL}$ was taken in a Sedgwick Rafter counting cell which was subsequently transferred to a microscope provided with a stage for counting. The zooplankton density was expressed as numbers $\mathrm{m}^{-3}$. One way ANOVA statistical analysis using SPSS (version 16) was performed to find out the significance of copepod abundance among the different stations in different months.

The zooplankton was subjected to species composition and population density. The statistical analysis such as species richness (d) of plankton sample was calculated by using the formula of Gleason (1922). The species diversity (H) of plankton sample was determined by using the formula of ShannonWiener (1949). Species evenness was calculated using the formula proposed by Pielou (1966) as Pielou's Evenness (J') Index and their biodiversity analysis is performed using PRIMER 6 software.

\section{Results and Discussion}

\section{Hydrology}

\section{Surface water temperature}

During the study period, the surface water temperature ranged between $24.3-30.1{ }^{\circ} \mathrm{C}$. In all the stations the lowest temperature was recorded between October and December (monsoon) and highest in the month of March and April (summer). The similar temperature ranges was reported by several workers (Prasad, 1957; Buddemeier and Hopley, 1998; Asha and Diwakar, 2007; Kumar and Geetha, 2012) in Gulf of Mannar region.

\section{Salinity}

During the present investigation, the salinity values were recorded in the range of 31.9 to $37.9 \%$. The high and low salinity observed during October and April respectively at station II. The salinity values recorded in the present study was similar to the studies conducted by Asha and Diwakar (2007) who registered the salinity in the range of (31.2 to $37.6 \%$ ) in Thoothukudi coastal water. The low salinity during northeast monsoon (October-November) may be due to the influence of monsoon. The high salinity during summer month (April-May) might be due to low amount of rainfall and high degree of evaporation of surface water. Similar observations were made by Kumar and Geetha (2012) in Gulf of Mannar region.

\section{Dissolved oxygen}

The DO values ranged between 3.1 and 6.3 $\mathrm{mL} \mathrm{L}^{-1}$. The maximum value was noticed at station III in November and minimum value of dissolved oxygen was observed at station II during March. In the current study, higher values of dissolved oxygen were recorded during monsoon season which might be due to the collective effect of heavy rainfall together with high wind velocity and therefore the resultant freshwater mixing. Dissolved oxygen showed an inverse relationship against temperature and salinity. The same observation was reported by many authors (Subramanian and Kannan, 1998; Paramasivam and Kannan, 2005).

\section{pH}

In the present investigation, $\mathrm{pH}$ values were ranged between 7.8 and 8.3. The maximum and minimum $\mathrm{pH}$ observed in station I during April and December respectively. The present $\mathrm{pH}$ range was similar to the study of Gopinath and Rodrigo (1991) who observed that a 
similar $\mathrm{pH}$ values of (7.8-8.15) in Tuticorin coastal water. The maximum $\mathrm{pH}$ observed during summer and correspondingly minimum $\mathrm{pH}$ was recorded during monsoon season could be due to the entry of freshwater. The recorded high summer $\mathrm{pH}$ values might be due to the influence of sea water penetration and high biological activity (Balasubramanian and Kannan 2005) and due to the presence of high photosynthetic activity (Sridhar et al., 2006; Saravanakumar et al., 2008). There is no significant difference $(\mathrm{P}>0.05)$ in water temperature, salinity, $\mathrm{pH}$ and dissolved oxygen values within the stations during the present study.

Species composition and diversity of copepod

During the study period 56 species of copepods were recorded which belongs to 20 families and four orders namely Calanoida, Harpacticoida, Cyclopoida and Poecilostomatoida (Table 1). The overall percentage of copepod species composition was in the following order: Calanoida (35 numbers; 62.5\%), Poecilostomatoida (9 numbers; 16.1\%), Harpacticoida (8 numbers; $14.3 \%$ ) and Cyclopoida (4 numbers; $7.14 \%$ ). In both station I and IV, 47 species of copepods were recorded; In station II, 44 species and in station III, 40 species were recorded (Table 2).

Under the order calanoida 9 families and 35 species have been recorded. In calanoid copepods Acartia was the dominant genus which representing 5 species followed by Pseudodiaptomus with 4 species. In Cyclopoida order, Oithonidae was the one and only family recorded with 4 species; Oithona was the dominant genus in this order. Under Harpacticoida 8 species were recorded under 6 families where Longipedia and Micosettella were the major genus by representing two species each. In case of Poecilostomatoida order, 4 families, 7 genus and 9 species were registered; Out of 7 genus recorded, Corycaeus was the dominant genus in this order which comprises 2 species. The present study is supported by Shanthi and Ramanibai (2011) who reported that Calanoid copepods were most diverse group represented by 31 species in Chennai Coast (Cooum and Adyar), Bay of Bengal. Similarly, Fernandes and Ramaiah (2009) found that Calanoids were the predominant copepods in the Bay of Bengal which represents 132 species in a total of 163 species recorded.

Species richness (D), species diversity (H) and species evenness $(\mathbf{J})$

The species richness index (D) for copepods ranged between 0.48 and 2.72. The maximum was observed during March at station IV and the minimum value was observed during December at station III. The species diversity index $(\mathrm{H})$ for zooplankton ranged between 0.87 and 1.98. The high species diversity recorded during March and minimum species diversity was recorded in the month of December at station IV and III respectively. The species evenness varied from 0.24 to 0.51 in station III and I. The lowest and highest value noticed during December and October month. The Maximum range of species richness, species diversity and species evenness recorded in summer season. The minimum values of species richness, diversity and evenness noticed during December in all the four stations. This lowest value during monsoon season could be attributed to rainfall influx and salinity variation.

\section{Dominance plot}

The dominance plot or k-dominance curve was constructed on the data sets to find out the copepod biodiversity pattern over the station and months and the results were shown in the Figure 1a and $\mathrm{b}$. In the station wise plot curve 
for the Punnakayal lies on the lower side, extends further and rises slowly due to presence of more number of species whereas the curve for Vembar reaches the cumulative $100 \%$ due to more number species as evident in the $x$-axis. Similarly, month-wise $\mathrm{k}$ dominance plot reveals that more dominance of few copepod species was evident during March, 2012 and less dominance in October, 2011 whereas the curve for October, 2011 reaches first due to more number of species. In the typical undisturbed ecosystem the kdominance curve is S-shaped and from the figure $2 \mathrm{a}$ and $\mathrm{b}$ clearly indicates that the curve showed a gentle slope with medium starting point indicating medium diversity with little disturbance.

\section{Bray-Curtis similarity coefficient}

The station wise Bray-Curtis similarity coefficient (Table 3 and 4) reaveals that the highest similarity was found between Punnakayal and Vembar with $80.43 \%$ similarity followed by Vembar and Keelavaipar shows $78.23 \%$ similarity. The month-wise similarity was found to be high between March 2012 and January 2012 (76.64\%).

\section{Cluster analysis}

The cluster analysis (or classification) or dendrogram (Figure $2 \mathrm{a}$ and $\mathrm{b}$ ) revealed grouping of sites in the stations and months during the study period.

\section{Bubble plot}

Similar to cluster analysis, the same pattern was also evident in the MDS plot again demonstrating the close similarity in species composition among the sites. The sites lying closer have more similarity in species composition and abundance vice versa for the sites lying far apart. MDS for copepods recorded during different period showing good ordination and it reveals the goodness of fit. In the MDS bubble plot, the abundance of copepods species and dissimilarity between the sites was superimposed as circles of different sizes. The bubble plots give the abundance of discriminating dominant copepod species and it is evident from the size of the bubble where greater the bubble size higher the abundance of the copepod species. The bubble plots of the Euterpina acutifrons, Oithona brevicornis, Acrocalanus gracilis and Corycaeus crassiusculus for four different stations was given in the figure $3 \mathrm{a}-\mathrm{d}$.

\section{Confidence funnel}

The $95 \%$ confidence funnel generated for the average taxonomic distinctness index $\left(\Delta^{+}\right)$and variation in taxonomic distinctness values (lamda+) of all the months was shown in Figure 4 and 5 respectively. During the observation period, in all month and stations the fitted $95 \%$ probability contours of average taxonomic distinctness (delta+) was well inside the confidence funnel showing no statistically significant deviation from the normal deviation in taxonomic copepod species diversity (CSD) between the months and stations. Similarly, the $95 \%$ confidence funnel for variation in taxonomic distinctness values (lamda+) showed similar trend as that of average taxonomic distinctness (delta+) for both month-wise and station-wise (CSD).

\section{Confidence ellipse}

The $95 \%$ confidence ellipse plot generated for average taxonomic distinctness (delta+) and variation in taxonomic distinctness (lambda+). In the ellipse plot of the average taxonomic distinctness and variation in taxonomic distinctness values, shows no statistically significant departure from the ellipse for all the observation months and stations which can be seen clearly from figure $6 a$ and $b$. 
Table.1 Copepod species composition of study sites during the period of study

\begin{tabular}{|c|c|c|c|c|c|c|c|}
\hline Order & Family & Genus & Species & S I & S II & S III & S IV \\
\hline \multirow[t]{33}{*}{ Calanoida } & Acartiidae & Acartia & Acartia centrura & + & + & - & + \\
\hline & & & Acartia danae & + & + & - & - \\
\hline & & & Acartia erythraea & + & + & + & + \\
\hline & & & Acartia spinicauda & + & + & + & + \\
\hline & & & Acartia southwelli & + & - & + & + \\
\hline & Paracalanidae & Acrocalanus & Acrocalanus gibber & + & + & - & - \\
\hline & & & Acrocalanus gracilis & + & + & + & + \\
\hline & & Paracalanus & Paracalanus parvus & + & + & + & + \\
\hline & Pontellidae & Calanopia & Calanopia aurivilli & - & + & - & + \\
\hline & & & Calanopia elliptica & + & + & + & + \\
\hline & & & Calanopia minor & + & + & + & + \\
\hline & & Labidocera & Labidocera acuta & + & + & + & + \\
\hline & & & Labidocera pavo & + & - & - & + \\
\hline & & & Labidocera pectinata & + & + & + & + \\
\hline & & Pontella & Pontella danae & - & + & - & + \\
\hline & Calanidae & Canthocalanus & $\begin{array}{l}\text { Canthocalanus } \\
\text { pauper }\end{array}$ & + & + & - & + \\
\hline & & & Canthocalanus sp & + & + & - & + \\
\hline & & Nannocalanus & Nannocalanus minor & + & + & + & + \\
\hline & & Undinula & Undinula vulgaris & + & - & + & + \\
\hline & Centropagidae & Centropages & $\begin{array}{l}\text { Centropages } \\
\text { dorsispinatus }\end{array}$ & - & - & + & - \\
\hline & & & Centropages furcatus & + & + & + & + \\
\hline & & & $\begin{array}{l}\text { Centropages } \\
\text { tenuiremis }\end{array}$ & - & + & + & + \\
\hline & & Isias & Isias tropica & - & - & - & + \\
\hline & Eucalanidae & Subeucalanus & $\begin{array}{l}\text { Subeucalanus } \\
\text { crassus }\end{array}$ & - & + & - & - \\
\hline & & & $\begin{array}{l}\text { Subeucalanus } \\
\text { monachus }\end{array}$ & + & - & - & + \\
\hline & & Eucalanus & Eucalanus elongatus & + & - & + & + \\
\hline & & & Eucalanus sp. & + & - & + & + \\
\hline & $\begin{array}{l}\text { Pseudodiapto } \\
\text { midae }\end{array}$ & $\begin{array}{l}\text { Pseudodiapto } \\
\text { mus }\end{array}$ & $\begin{array}{l}\text { Pseudodiaptomus } \\
\text { spinipes }\end{array}$ & + & + & - & + \\
\hline & & & $\begin{array}{l}\text { Pseudodiaptomus } \\
\text { aurivilli }\end{array}$ & + & + & + & - \\
\hline & & & $\begin{array}{l}\text { Pseudodiaptomus } \\
\text { serricaudatus }\end{array}$ & + & + & - & + \\
\hline & & & Pseudodiaptomus sp. & + & + & + & + \\
\hline & Temoridae & Temora & Temora discaudata & + & + & - & - \\
\hline & & & Temora stylifera & + & + & + & - \\
\hline
\end{tabular}


Int.J.Curr.Microbiol.App.Sci (2018) 7(4): 2767-2792

\begin{tabular}{|c|c|c|c|c|c|c|c|}
\hline & & & Temora turbinata & + & + & + & + \\
\hline & Tortanidae & Tortanus & Tortanus gracilis & + & + & + & + \\
\hline \multirow[t]{4}{*}{ Cyclopoida } & Oithonidae & Oithona & Oithona brevicornis & + & + & + & + \\
\hline & & & Oithona linearis & + & + & + & + \\
\hline & & & Oithona similis & + & + & + & + \\
\hline & & Dioithona & Dioithona rigida & + & + & + & + \\
\hline \multirow[t]{8}{*}{$\begin{array}{l}\text { Harpactico } \\
\text { ida }\end{array}$} & Peltidiidae & Clytemnestra & $\begin{array}{l}\text { Clytemnestra } \\
\text { scutellata }\end{array}$ & + & + & + & + \\
\hline & Euterpinidae & Euterpina & Euterpina acutifrons & + & + & + & + \\
\hline & Longipediidae & Longipedia & Longipedia coronata & + & + & + & - \\
\hline & & & Longipedia weberi & + & + & + & + \\
\hline & Miraciidae & Macrosetella & Macrosetella gracilis & + & + & + & + \\
\hline & Metidae & Metis & Metis jousseaumei & + & + & + & + \\
\hline & Ectinosomatidae & Microsetella & $\begin{array}{l}\text { Microsetella } \\
\text { norvegica }\end{array}$ & + & + & + & + \\
\hline & & & Microsetella rosea & + & + & + & + \\
\hline \multirow{9}{*}{$\begin{array}{l}\text { Poecilosto } \\
\text { matoida } \\
\end{array}$} & Bomolochidae & Bomolochus & Bomolochus sp. & + & - & + & + \\
\hline & Sapphirinidae & Copilia & Copilia mirabilis & - & + & + & - \\
\hline & & & Copilia vitrea & - & - & - & + \\
\hline & & Sapphirina & $\begin{array}{l}\text { Sapphirina } \\
\text { nigromaculata }\end{array}$ & + & + & - & + \\
\hline & Corycaeidae & $\begin{array}{l}\text { Onchocoryca } \\
\text { eus }\end{array}$ & $\begin{array}{l}\text { Onchocorycaeus } \\
\text { catus }\end{array}$ & + & + & + & + \\
\hline & & Corycaeus & $\begin{array}{l}\text { Corycaeus } \\
\text { crassiusculus }\end{array}$ & + & + & + & + \\
\hline & & Corycaeus & Corycaeus speciosus & + & - & + & + \\
\hline & & Farranula & Farranula gibbula & - & - & + & + \\
\hline & Oncaeidae & Oncaea & Oncaea venusta & + & + & + & + \\
\hline
\end{tabular}

S I- Station I (Vembar); S II- Station II (Keelavaipar); S III- Station III (Punnakayal); S IV- Station IV (Thiruchendur)

(+) indicates presence of a copepod

$(-)$ indicates absence of copepod

Table.2 Month wise species percentage in all four stations during the study period

\begin{tabular}{|l|l|l|l|l|}
\hline Coppepoda groups & Vembar & Keelavaipar & Punnakayal & Thiruchendur \\
\hline Calanoida & $29(61.70 \%)$ & $27(61.36 \%)$ & $21(52.50 \%)$ & $28(59.57 \%)$ \\
\hline Cyclopoida & $4(8.51 \%)$ & $4(9.09 \%)$ & $4(10.00 \%)$ & $4(8.51 \%)$ \\
\hline Harpacticoida & $8(17.02 \%)$ & $8(18.18 \%)$ & $8(20.00 \%)$ & $7(14.89 \%)$ \\
\hline Poecilostomatoida & $6(12.77 \%)$ & $5(11.36 \%)$ & $7(17.50 \%)$ & $8(17.02 \%)$ \\
\hline
\end{tabular}

Percentage value is given in parenthesis 
Table.3 Bray-Curtis similarity for copepods observed over different stations during the study period

\begin{tabular}{|l|l|l|l|l|}
\hline Stations & Vembar & Keelavaipar & Punnakayal & Thiruchendur \\
\hline Vembar & & & & \\
\hline Keelavaipar & 78.23 & & & \\
\hline Punnakayal & 75.88 & 76.05 & \\
\hline Thiruchendur & 76.6 & 74.17 & 80.43 & \\
\hline
\end{tabular}

Table.4 Bray-Curtis similarity for copepods observed over different months during the study period

\begin{tabular}{|l|l|l|l|l|l|l|l|}
\hline Months & Oct-11 & Nov-11 & Dec-11 & Jan-12 & Feb-12 & Mar-12 & Apr-12 \\
\hline Oct-11 & & & & & & & \\
\hline Nov-11 & 72.34 & & & & & & \\
\hline Dec-11 & 67.04 & 62.7 & & & & & \\
\hline Jan-12 & 69.94 & 62.12 & 68.31 & & & & \\
\hline Feb-12 & 70.55 & 71.49 & 70.07 & 75.49 & & & \\
\hline Mar-12 & 66.98 & 63.5 & 66.74 & 76.64 & 76.37 & & \\
\hline Apr-12 & 63.51 & 55.37 & 59.79 & 74.16 & 68.83 & 75.08 & \\
\hline
\end{tabular}

Fig.1 a and b Station-wise (a) and month-wise (b) dominance plot for copepods during 20112012

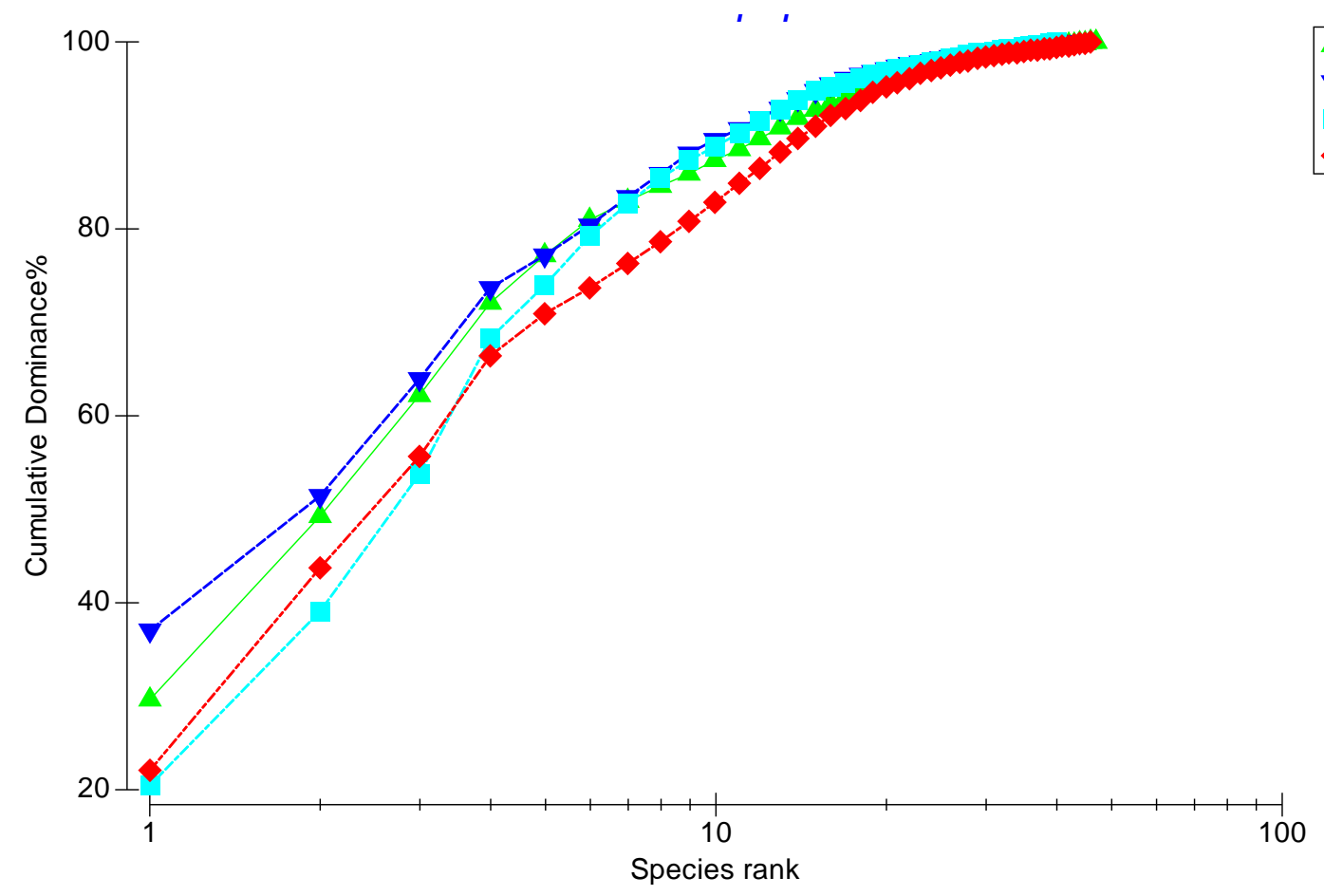




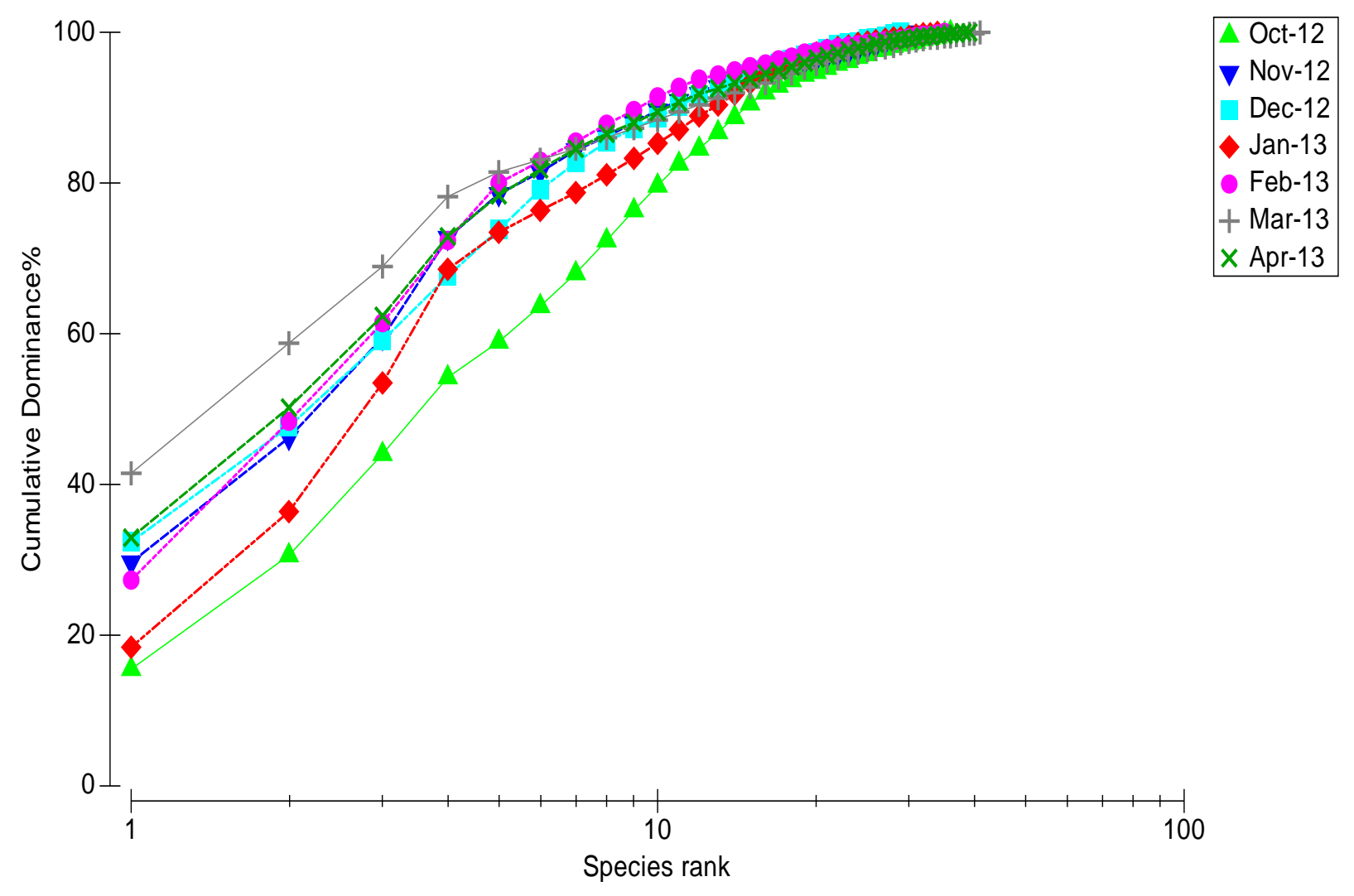

Fig.2 a and b Dendrogram of copepods recorded in various stations (a) and months (b)

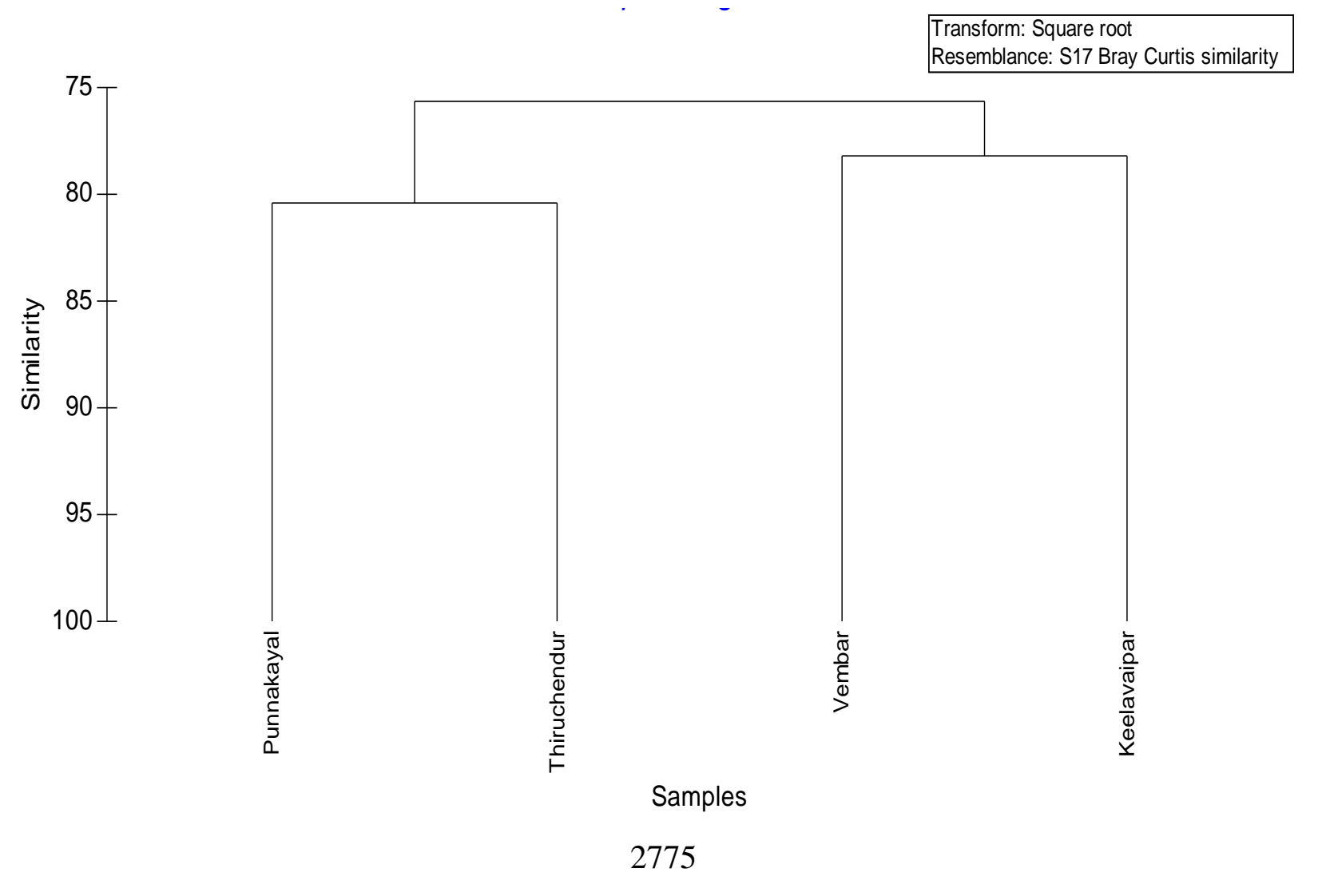




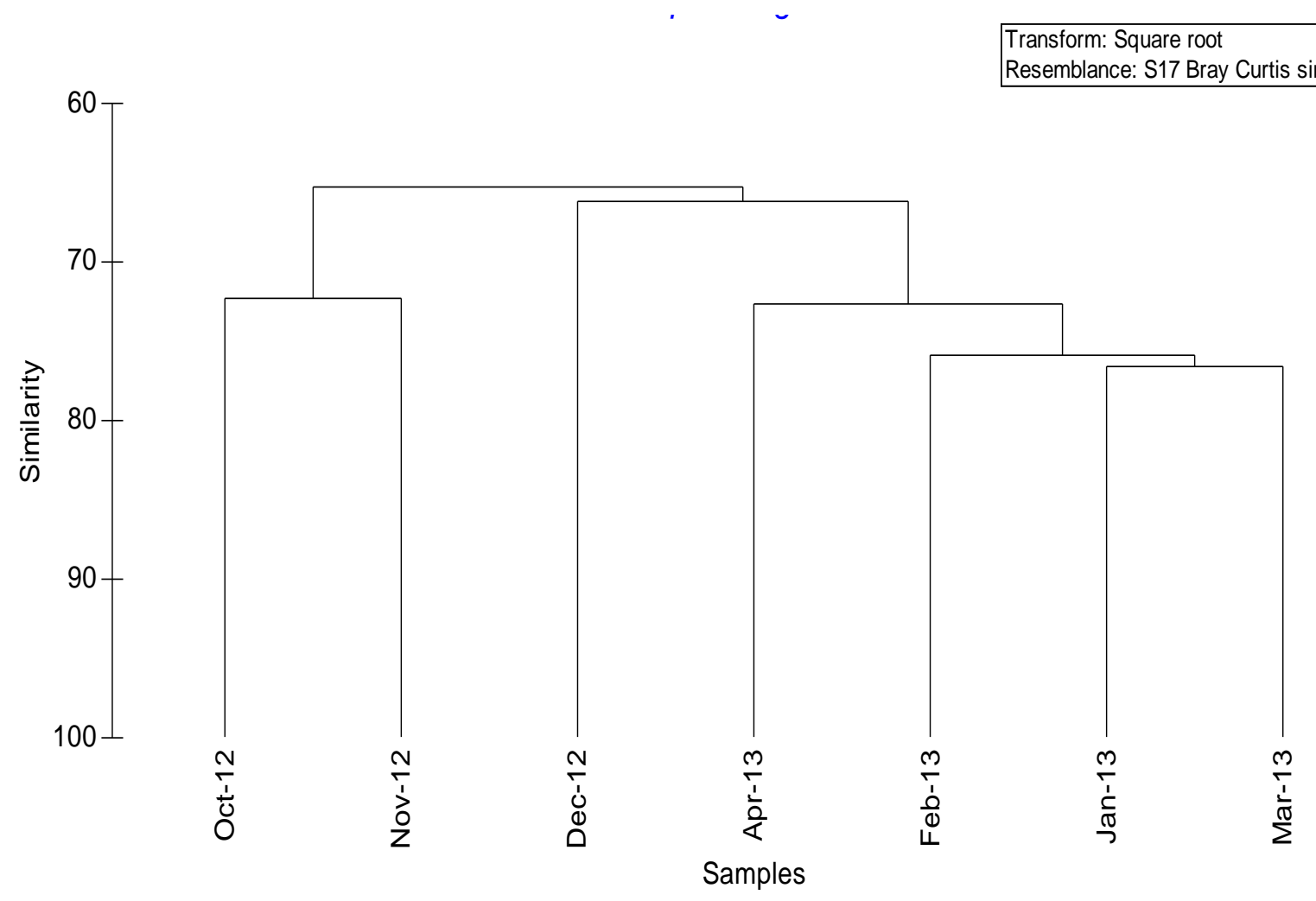

Fig.3a Bubble plot for Euterpina acutifrons

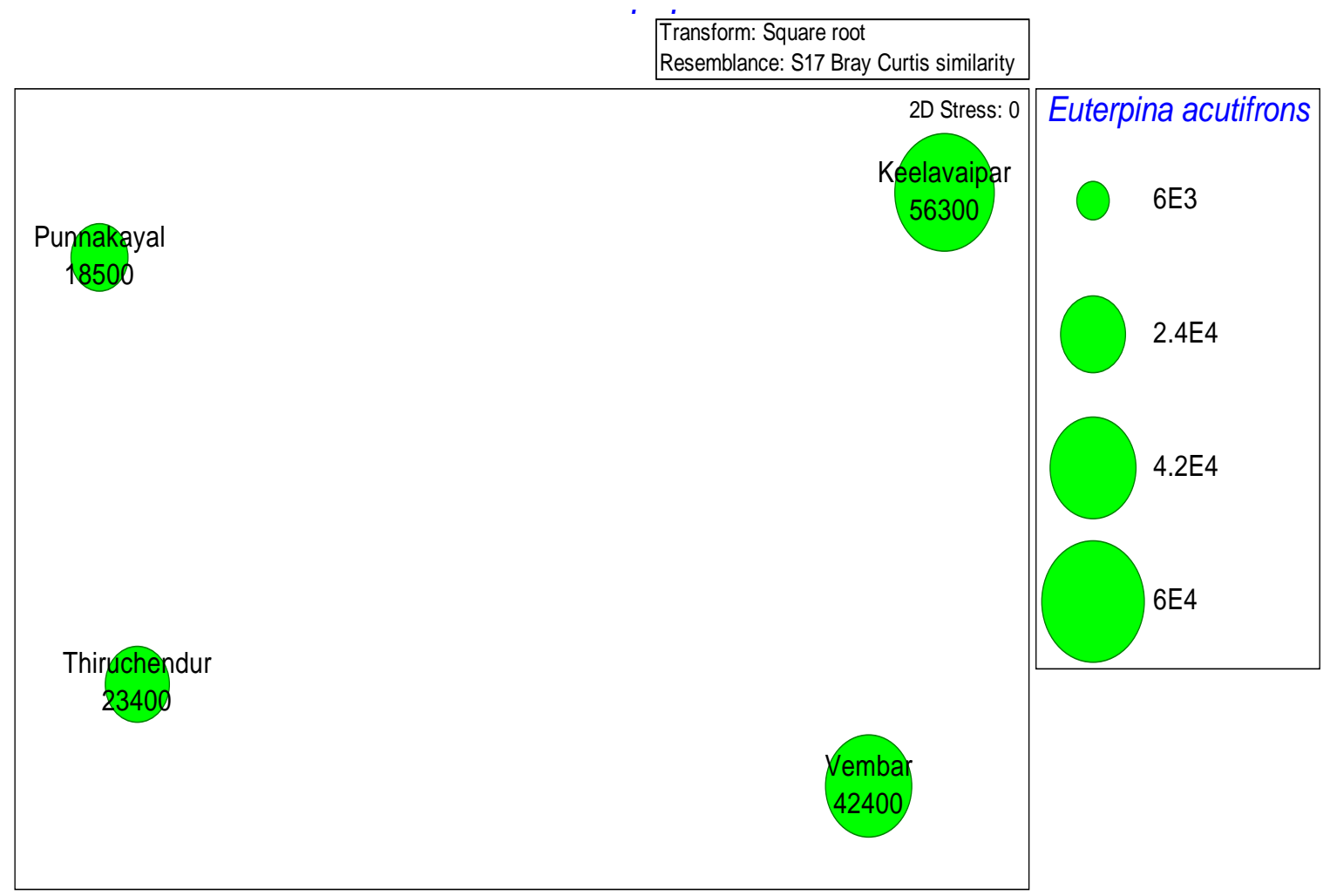


Int.J.Curr.Microbiol.App.Sci (2018) 7(4): 2767-2792

Fig.3b Bubble plot for Oithona brevicornis

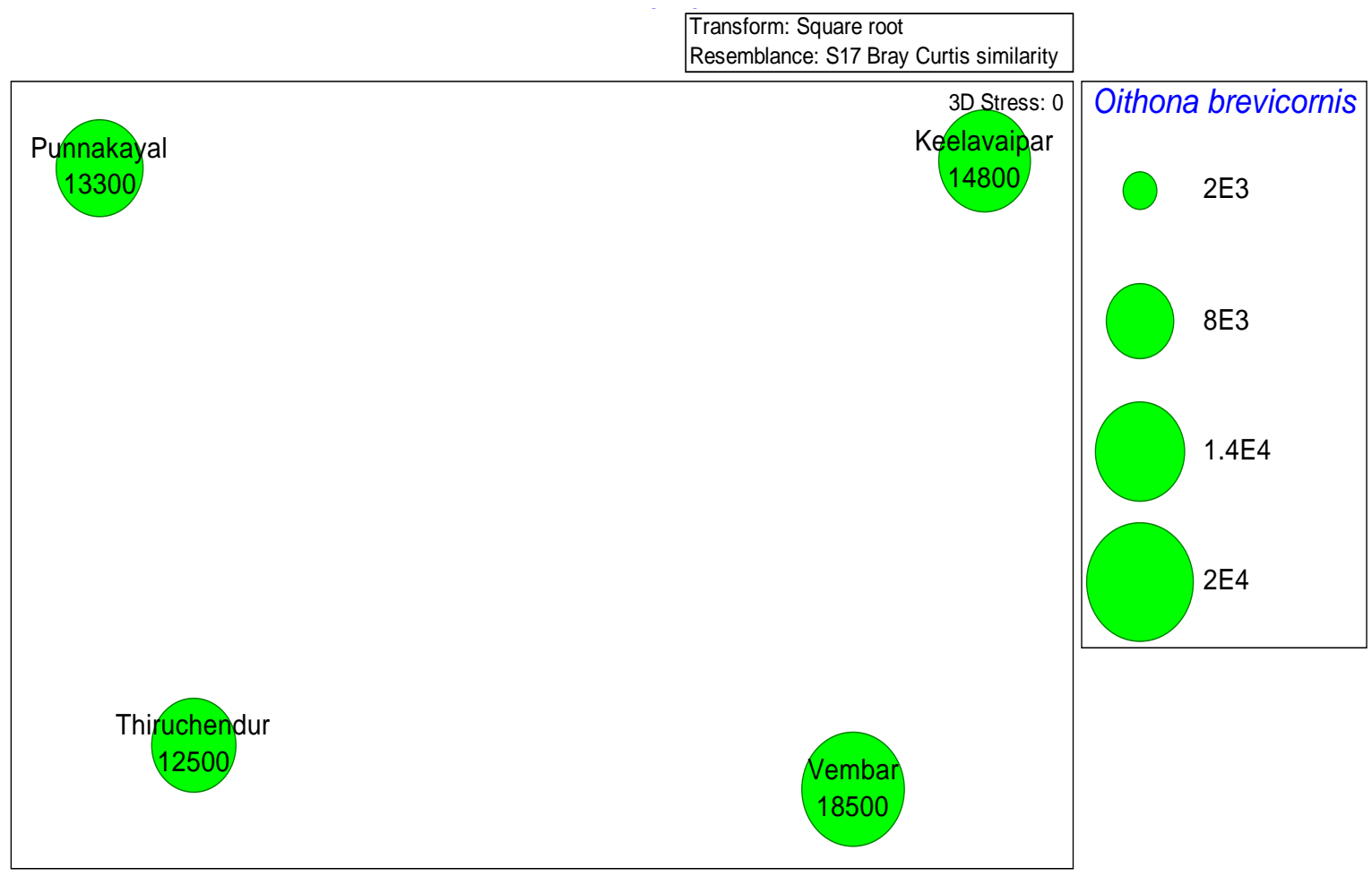

Fig.3c Bubble plot for Acrocalanus gracilis

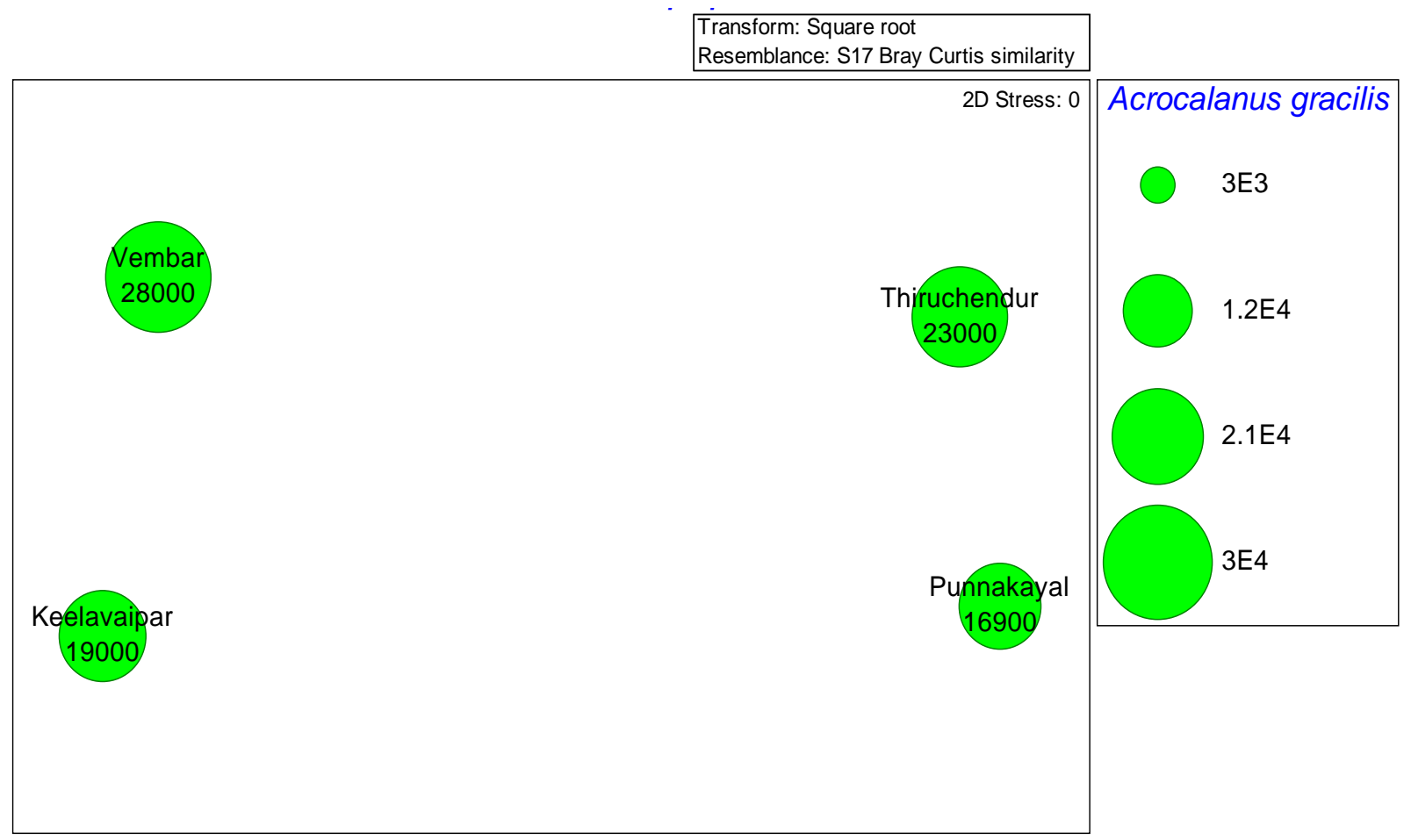


Fig.3d Bubble plot for Corycaeus crassiusculus

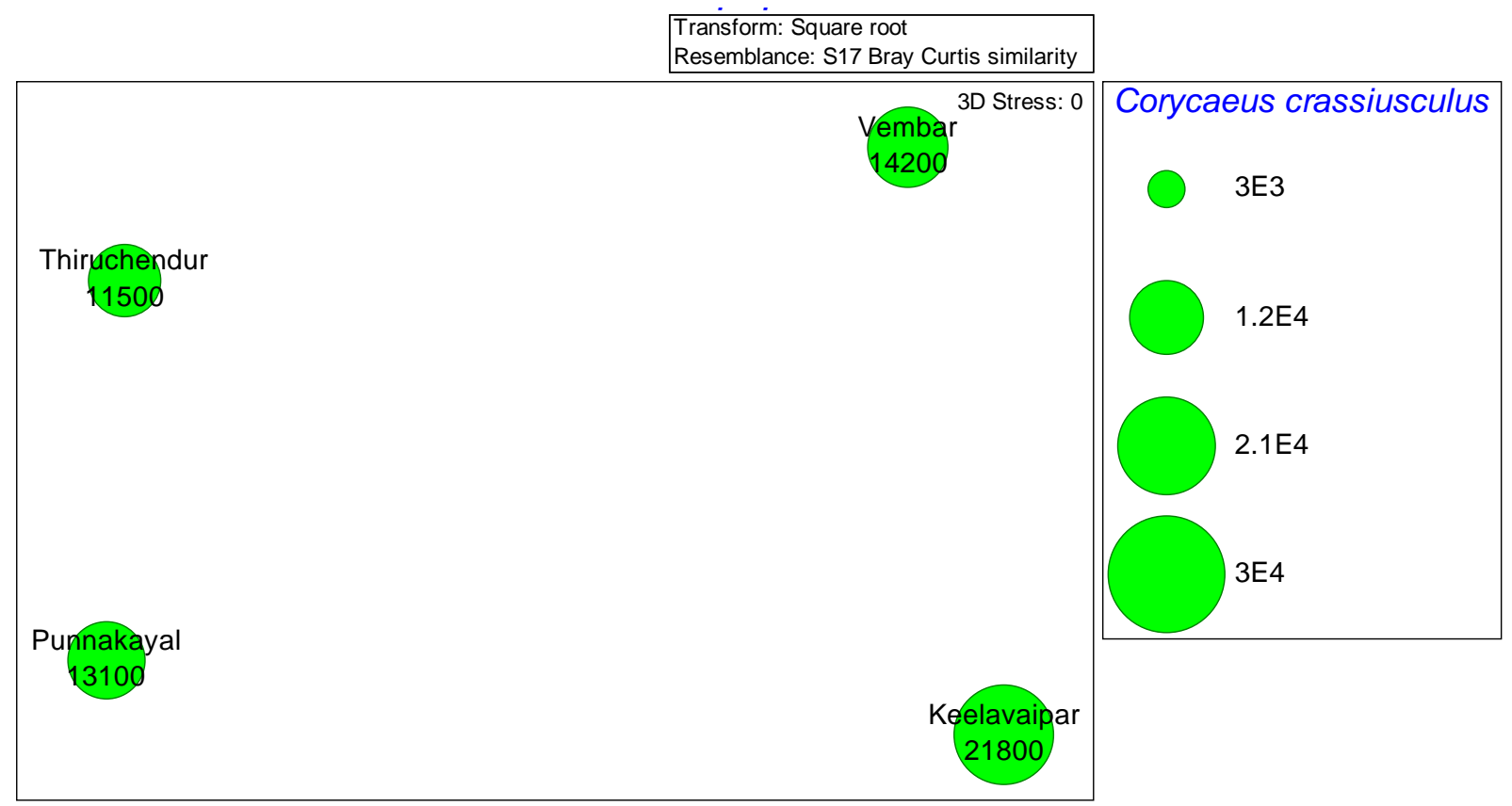

Fig.4 The $95 \%$ confidence funnel for average taxonomic distinctness values (delta+) showing site-wise (a) and month-wise (b) higher/lower copepod diversity and deviation from the normal distribution from the mean delta+ as dotted line

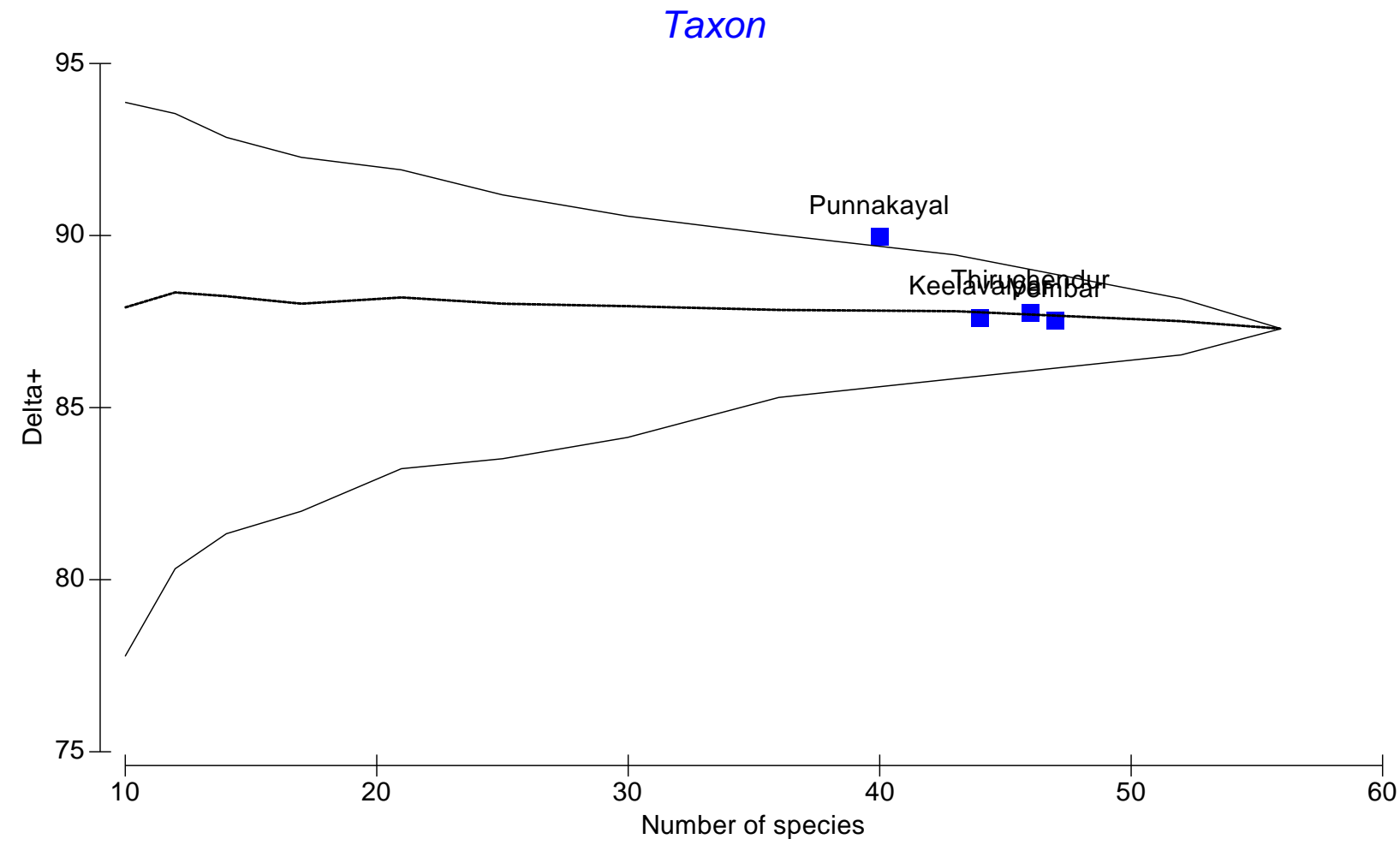




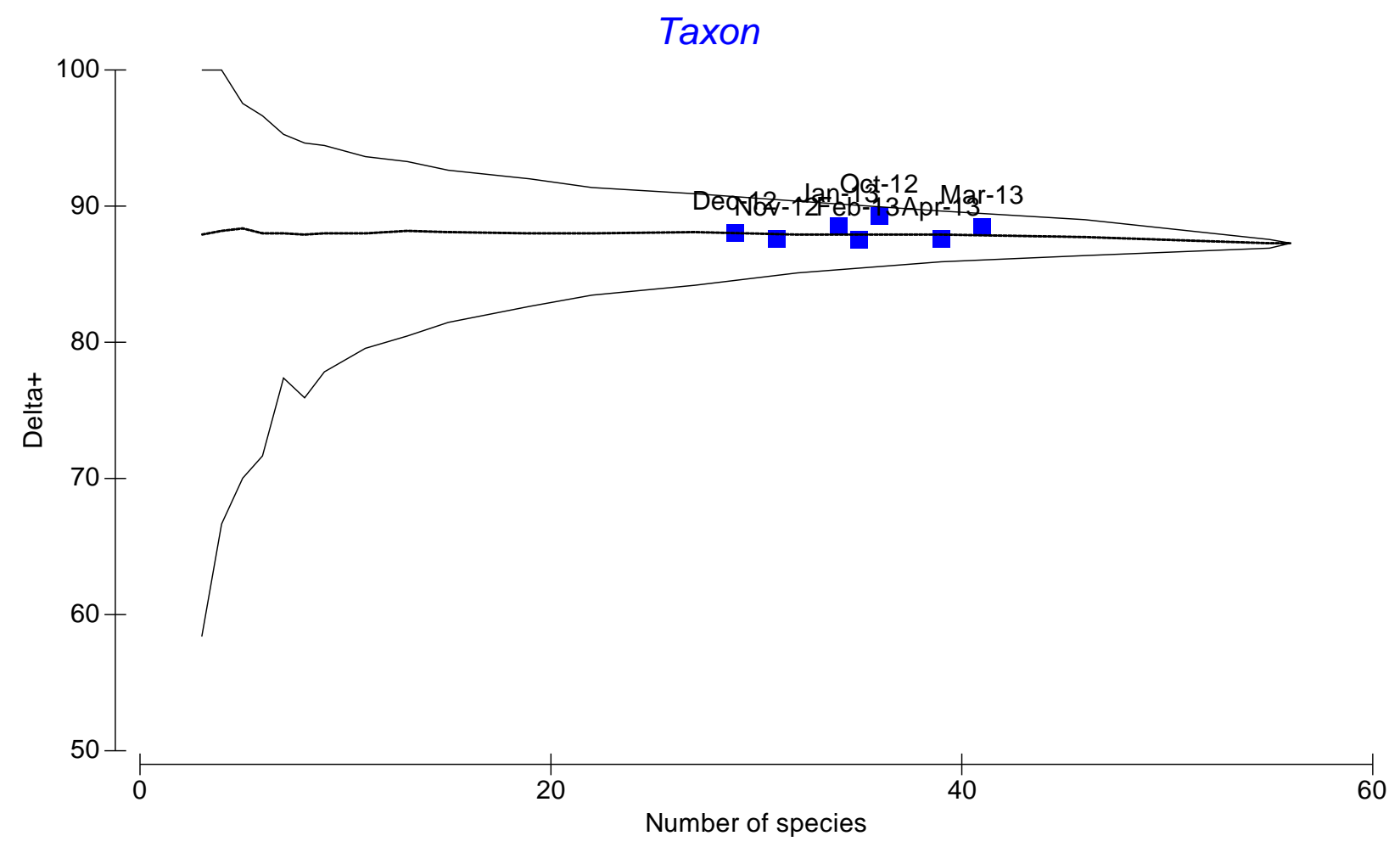

Fig.5 The $95 \%$ confidence funnel for variation in taxonomic distinctness values (lamda+) showing month-wise (a) and station-wise (b) higher/lower copepod diversity and deviation from the normal distribution from the mean lamda + as dotted line

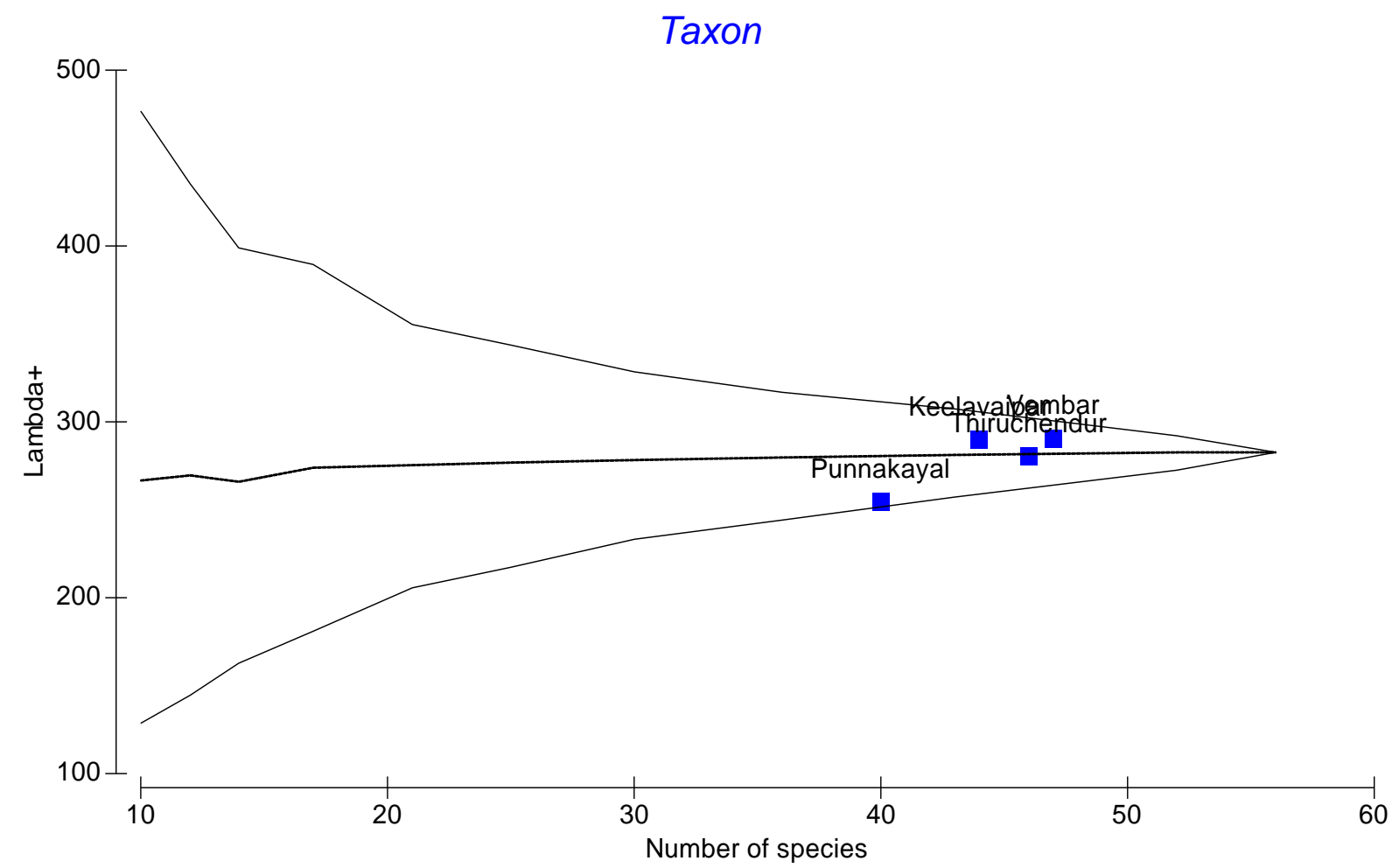




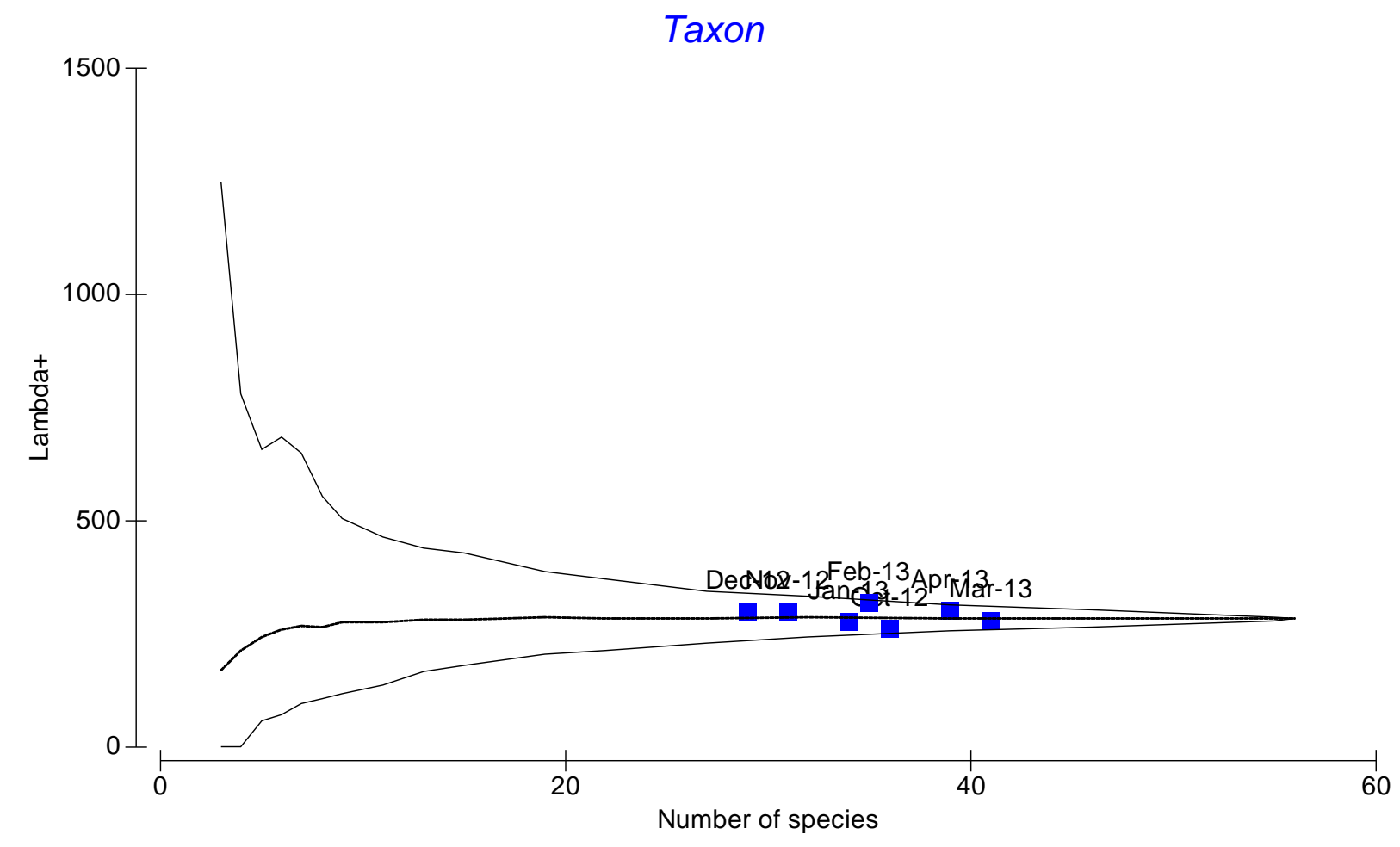

Fig.6 Fitted $95 \%$ probability contours of (a) average taxonomic distinctness (delta+) and (b) variation in taxonomic distinctness (lamda+), showing no statistically significant deviation in copepod diversity between months (a) and stations (b)

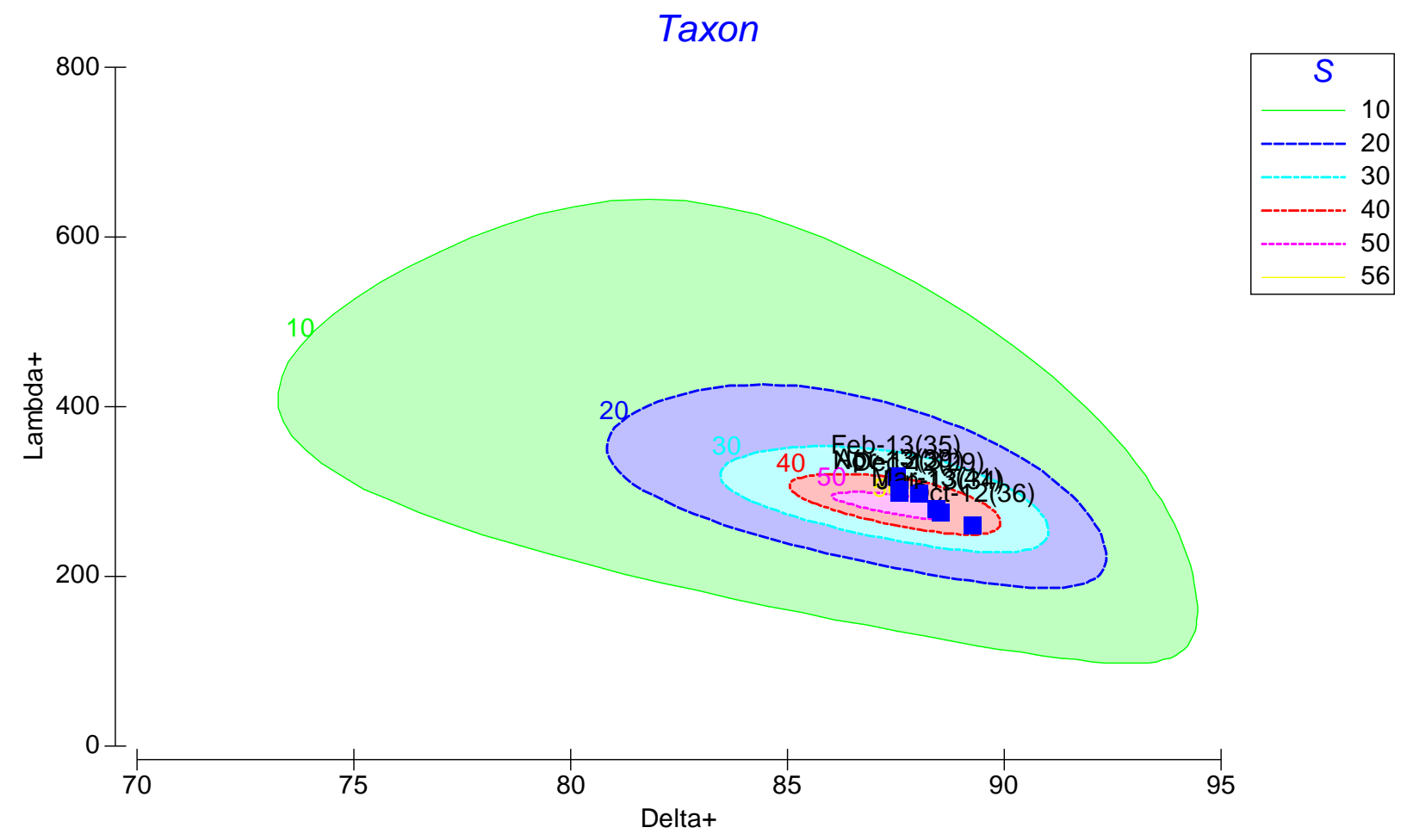




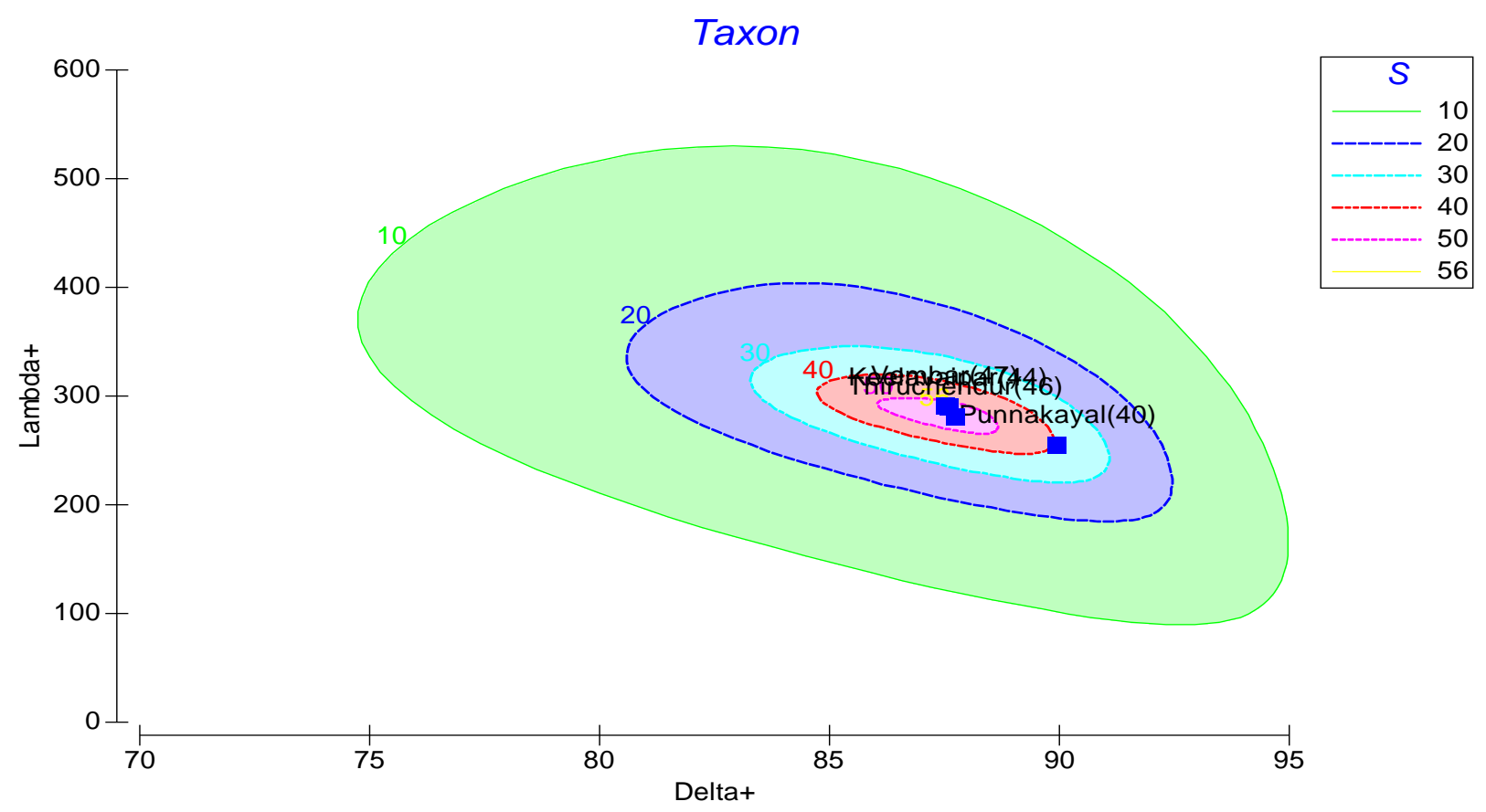

Fig.7a LINKTREE, showing divisive clustering of stations from species composition, constrained by inequalities on one variable (copepods biomass) with ANOSIM R value and B \% for each split
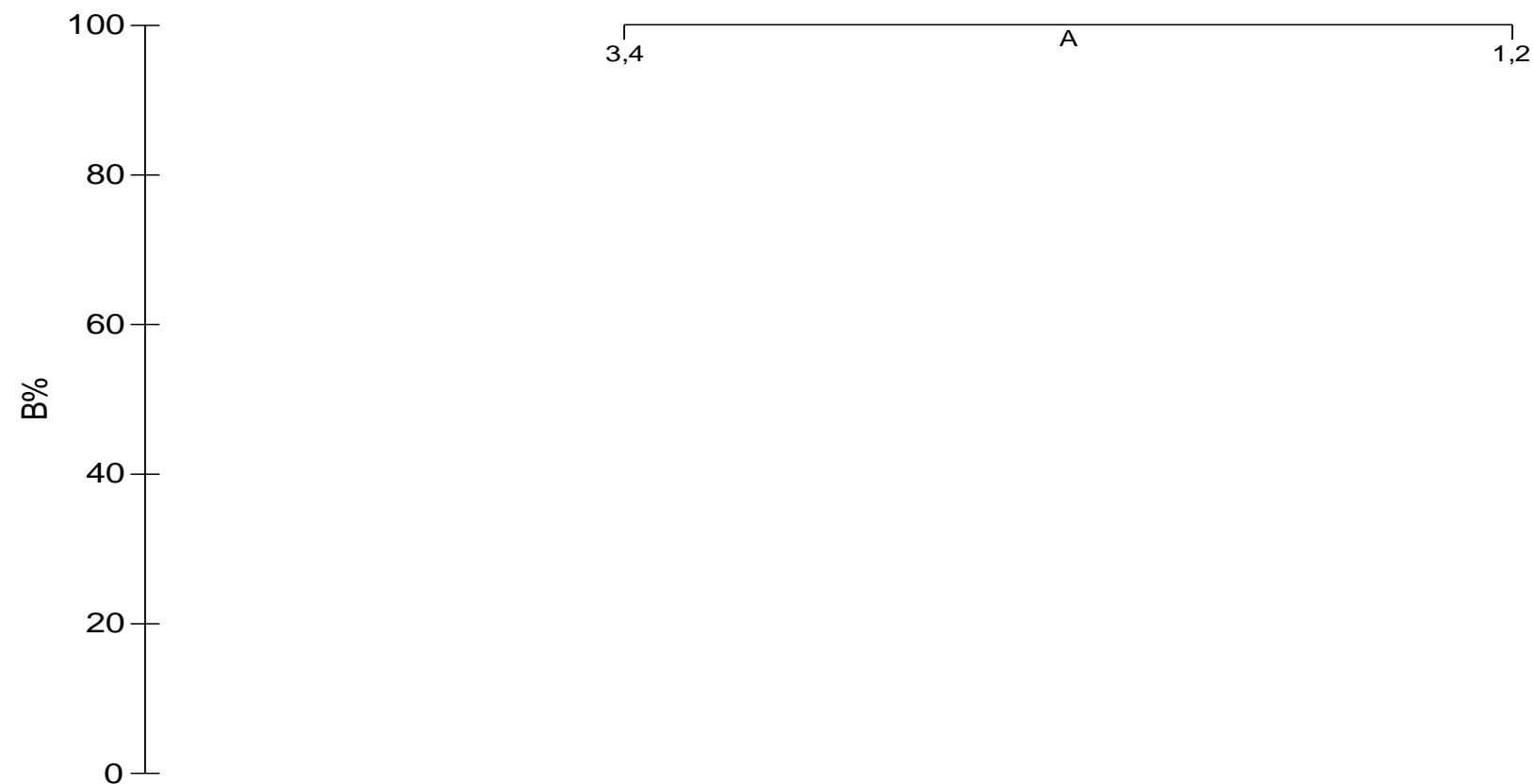

A: $\mathrm{R}=1.00 ; \mathrm{B} \%=100 ;$ Farranula gibbula $>100(<0)$ or Pseudodiaptomus spinipes $<100(>300)$ or Acartia southwelli $>2.6 \mathrm{E} 3(<800)$ or Euterpina acutifrons $<2.34 \mathrm{E} 4(>4.24 \mathrm{E} 4)$ or Labidocera acuta $<500(>900)$ or Eucalanus elongatus $>200(<100)$ or Temora turbinata $<5.2 \mathrm{E} 3(>5.4 \mathrm{E} 3)$ or Temora discaudata $<0(>300)$ or Oithona brevicornis $<1.33 \mathrm{E} 4(>1.48 \mathrm{E} 4)$ or Paracalanus parvus $<2.4 \mathrm{E} 3(>2.9 \mathrm{E} 3)$ or Calanopia minor $<900(>1.8 \mathrm{E} 3)$ or Oithona linearis $>2.1 \mathrm{E} 3(<1.6 \mathrm{E} 3)$ or Corycaeus crassiusculus $<1.31 \mathrm{E} 4(>1.42 \mathrm{E} 4)$ or Microsetella rosea $>200(<100)$ or Acrocalanus gibber $<0(>200)$ or Acartia danae $<0(>100)$ 
1 to 4 respective stations from I to IV

Fig.7b LINKTREE, showing divisive clustering of months from species composition, constrained by inequalities on one variable (copepods biomass) with ANOSIM R value and B \% for each split
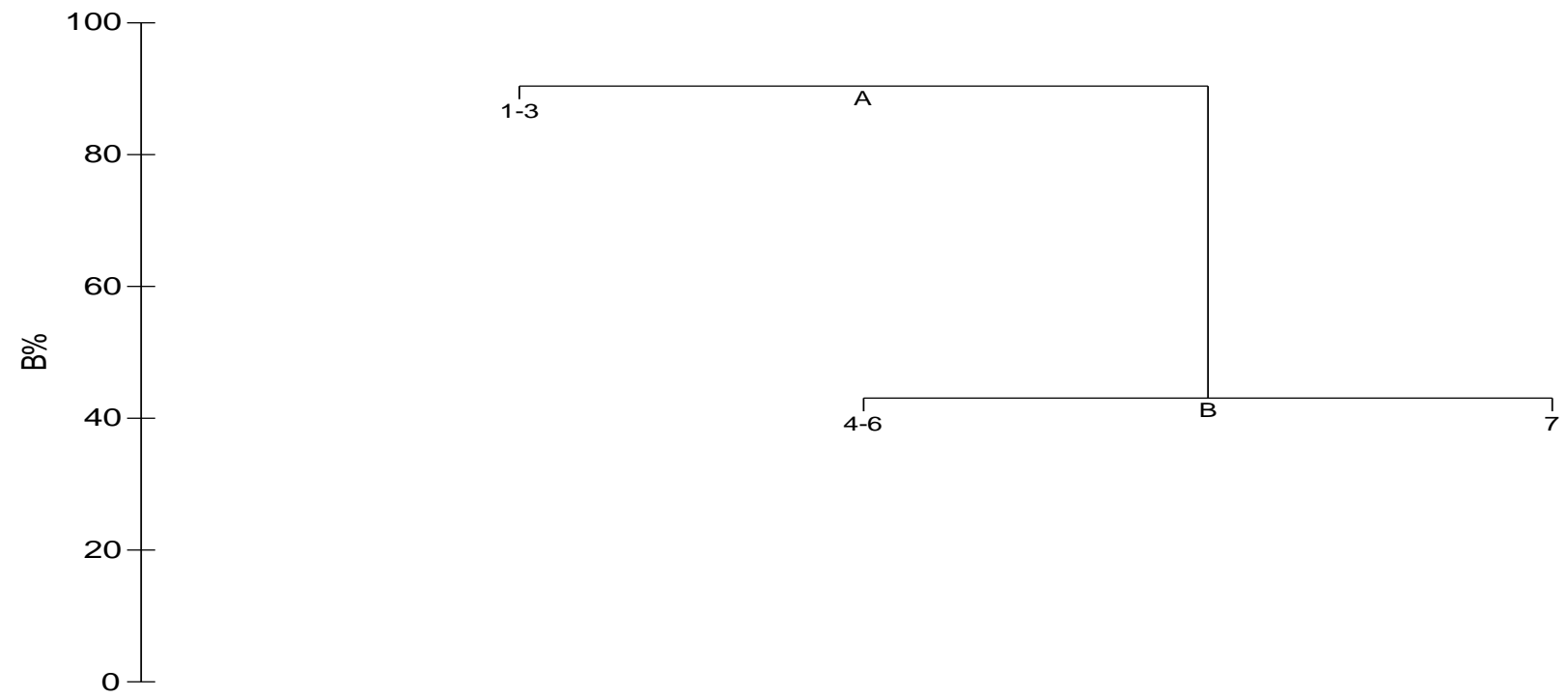

*1 to 12 is the respective months from October 2011 to April 2012

A: $\mathrm{R}=0.67 ; \mathrm{B} \%=90 ;$ Oithona brevicornis $<5.3 \mathrm{E} 3(>8.8 \mathrm{E} 3)$ or Temora turbinata $<2.2 \mathrm{E} 3(>3.2 \mathrm{E} 3)$ or Acrocalanus gracilis $<9.4 \mathrm{E} 3(>1.33 \mathrm{E} 4)$ or Tortanus gracilis $<0(>100)$ or Corycaeus crassiusculus $<6.4 \mathrm{E} 3(>7.4 \mathrm{E} 3)$ or Macrosetella gracilis $<300(>400)$ or Euterpina acutifrons $<1.34 \mathrm{E} 4(>1.42 \mathrm{E} 4)$

B: $\mathrm{R}=1.00 ; \mathrm{B} \%=43$; Temora discaudata $<0(>1 \mathrm{E} 3)$ or Temora stylifera $<100(>1.8 \mathrm{E} 3)$ or Canthocalanus $\mathrm{sp}<100(>800)$ or Calanopia minor $<1.1 \mathrm{E} 3(>7 \mathrm{E} 3)$ or Acartia centrura $<100(>500)$ or Metis jousseaumei $<100(>400)$ or Oithona linearis $<1.4 \mathrm{E} 3(>4.6 \mathrm{E} 3)$ or Longipedia weberi $<600(>1.7 \mathrm{E} 3)$ or Pseudodiaptomus aurivilli<0(>100) or Onchocorycaeus catus $<300(>700)$ or Corycaeus crassiusculus $<1.18 \mathrm{E} 4(>1.61 \mathrm{E} 4)$ or Paracalanus parvus $>1.2 \mathrm{E} 3(<900)$ or Acrocalanus gracilis $<1.69 \mathrm{E} 4(>2.28 \mathrm{E} 4)$ or Eucalanus elongatus $<200(>300)$ or Acartia danae $<2.2 \mathrm{E} 3(>2.7 \mathrm{E} 3)$ or Microsetella norvegica $<1.6 \mathrm{E} 3(>1.9 \mathrm{E} 3)$ or Oithona similis $>200(<100)$ or Macrosetella gracilis $>600(<400)$ or Nanocalanus minor $>700(<500)$ or Euterpina acutifrons $<4.06 \mathrm{E} 4(>4.33 \mathrm{E} 4)$ or Acrocalanus gibber $<0(>200)$

Fig.8 Biomass of major groups of copepods in the study site

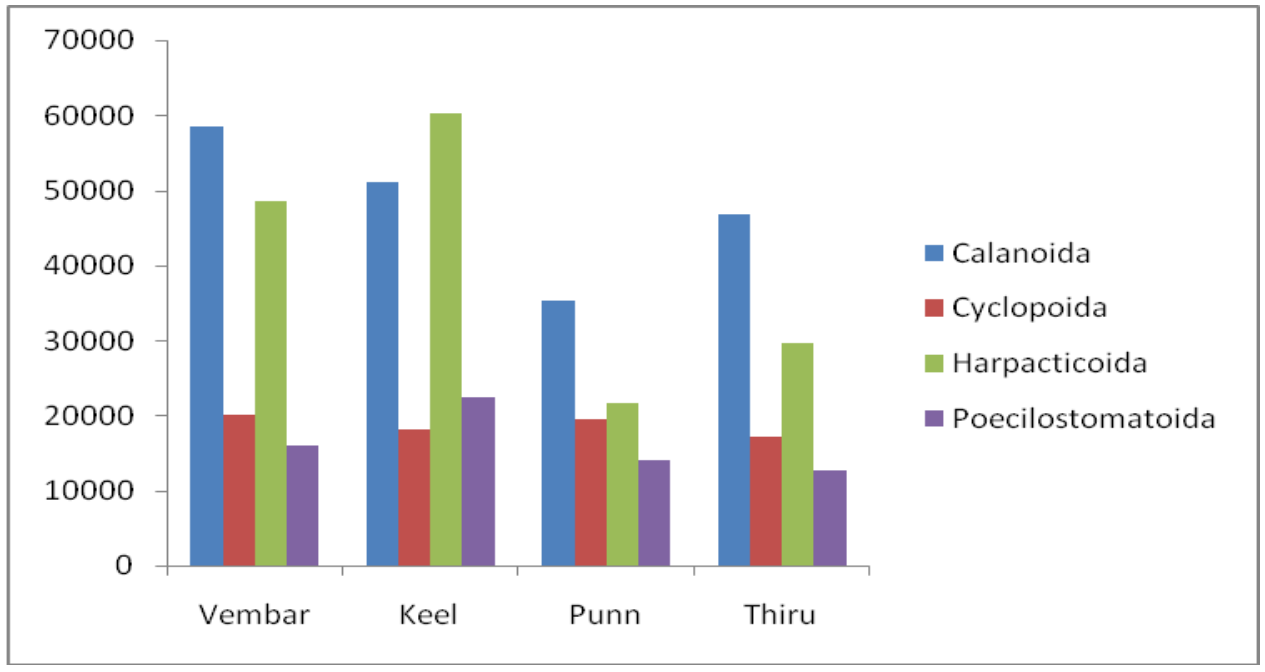




\section{Linkage tree}

Linkage tree are drawn to ascertain the difference in average rank dissimilarities between and within the groups by a threshold on one or more variables. Figure 4a shows the LINKTREE analysis for the stations and this is a dendrogram from divisive clustering of the stations, based on copepod species with partitions constrained by thresholds on species biomass. The split (A) in the divisive clustering between 3,4 and 1,2 giving an optimal $\mathrm{R}$ of 1.00 , with the division displayed on the $\mathrm{y}$-axis scale at $\mathrm{B} \%=100$. The split $\mathrm{A}$ separates from the others on the basis of few distinctly abundance copepod species shown in the Figure $7 \mathrm{a}$.

Figure $4 \mathrm{~b}$ shows the LINKTREE analysis for the months and this is a dendrogram from divisive clustering of the months, based on copepod species with partitions constrained by thresholds on species biomass. The first split $\mathrm{A}$ was at 2 and the remaining months giving an optimal $\mathrm{R}$ of 0.67 , with the division displayed on the $\mathrm{y}$-axis scale at $\mathrm{B} \%=90$. The split A separates form the others on the basis of variation in biomass between the 7 species (Oithona brevicornis, Temora turbinate, Acrocalanus gracilis, Tortanus gracilis, Corycaeus crassiusculus, Macrosetella gracilis, and Euterpina acutifrons).The next division (split b) and the remaining months giving an optimal $\mathrm{R}$ of 1.00 , with the division displayed on the $\mathrm{y}$-axis scale at $\mathrm{B} \%=43$. This split was between $(4,5,6)$ and (7) which separates from the others on the basis of few distinctly abundance species distinctly abundance copepod species shown in the Figure $7 b$.

\section{Population density of copepods}

During the study period, in population density Calanoid copepod was the dominant group which contributes $39 \%$ of the total population followed by Harpacticoid (33\%), Cyclopoid (15\%) and Poecilostomatoida (13\%). Among the families Euterpinidae, Paracalanidae, Oithonidae, Corycaeidae and Acartiidae were the major contributor in the total biomass and their biomass was given in Figure 8.

The results are on par with Sri Chandan (2015) who found that Calanoida was dominant order in total biomass of copepods in north western Bay of Bengal, Rushikulya estuary. Similarly, Gaonkar (2010) reported that order Calanoida was dominated among the copepod community from the ports of Mumbai. According to Pillai et al., (2014), the Calanoida were dominant group followed by Poeciliostomatoida and Cyclopoids showed relatively higher when compared to Harpacticoids in Andaman Islands. In the abundance of species of copepods, Calanoids formed foremost place, followed by Cyclopoids and Harpocticoids stood in Pay of Bengal and Gulf of Mannar (Kartha, 1959). As per the existing reports on copepod abundance in most of the cases Calanoids stood first but the abundance and dominance of other groups were varies due to prevailing environmental conditions. Moreover, in the present study the population density of other groups of copepods except Calanoids were not matching with the existing reports because the present study was conducted in Off shore regions of Gulf of Mannar.

\section{Calanoida}

Paracalanidae: Paracalanidae was the most dominant family in Calanoida order which contributed $52.9 \%$ biomass of Calanoida. Among the four species in this family, Acrocalanus gracilis was the major species. Acartidae: In this family five species belongs to the genus Acartia was encountered; species of this family contributed $13.9 \%$ of the total calanoid counts in the present study. Acartia spinicauda was the dominant species 
followed by Acartia southwelli. Temoridae: This is one of the dominant families in Calanoid group which contributes $12.6 \%$ of total calonoid population density. Three species under Temora genus recorded from this family and Temora turbinate was domineering species. Pontellidae: Seven species of this family were observed and constituted $9.3 \%$ of the Calanoida population. Among the three Calanopia species recorded, Calanopia minor was very common from this family. Calanidae: In total calanoida population $5.2 \%$ of population density was shared by Calanidae. From the four species of this family Nanocalanus minor was the prevalent species. Centropagidae: In this family, three genus belong to Centropages and one genus belongs to Isias were noticed. The share of $3.4 \%$ of population density was contributed by this family in Calanoida. Centropages furcatus occurs in large number in this family. Pseudodiaptomidae: In total calanoid biomass, Psedodiaptomidae registered $1.1 \%$ of share with four species belongs to the genus Pseudodiaptomus. Eucalanidae: Four species of this family contributes $1 \%$ of the overall calanoid count. Eucalanus sp was noticed to be predominant one of this family. Tortanidae: Tortanus gracilis was the single species recorded in this family and which represents very meagre amount $(0.5 \%)$ in calanoida group. In Calanoida, maximum population density was observed in the month of April where Acrocalanus gracilis was the dominat species. In all the months during the period of study, Acrocalanus gracilis was the dominant species followed by Temora turbinate, Calanopia minor and Acartia danae.

In Calanoida order, three families namely Paracalanidae, Acartidae and Temoridae were represents $78 \%$ of the total calanoid population. The remaining $22 \%$ population density was represented by rest of the five families registered during the study period The present study is in agreement with Pillai et al., (2014) who reported Paracalanidae was a dominant family in Andaman Islands. Similarly, the dominance of Paracalanidae and Acartidae families throughout the year was reported by Vineetha et al., (2015) from the tropical estuaries in Cochin. Conversely, the dominance of Acartidae was recorded in the inshore water of Chennai coast (Shanthi and Ramanibai, 2011). In Paracalanidae, Acrocalanus gracilis was the important species contributed maximum to the biomass. Kartha (1959) reported that three species, Acrocalanus gracilis, A. gibber and A. monachus from Gulf of Mannar and Palk Bay region and found short peak duration in May. Over all, calanoid copepod was most dominant than the rest of the 3 orders of copepods which is due to continuous breeding, high reproductive performance and ability to thrive in widely varying environmental conditions of calanoid copepod. This was in line with the results of Perumal et al., (2008) who found the dominance of calanoid copepod than the cyclopoid copepod in Parangipettai coast. There was significant difference $(\mathrm{P}<0.05)$ observed in calanoida population density in different stations as well as during different months. The overall maximum density of 58500 and 48300 numbers were noticed in Vembar station and April month respectively.

\section{Harpacticoida}

Euterpinidae: This family was the most prevalent family in this sub-order which alone possess $87.9 \%$ of total Harpacticoid population. Euterpina acutifrons was the most dominant species in Harpacticoid group and found in a large density during the entire study period. Ectinosomatidae: Two species recorded in this family and contributed $5.4 \%$ of total Harpacticoid counts. Microsetella norvegica was predominant species in 
Ectinosomatidae which exist throughout the study period. Miraciidae: This family was represented by the single species Macrosetella gracilis which accounts $3.1 \%$ of total Harpacticoid count. Longipediidae family was composed of two species which contributing $2.4 \%$ of Harpacicoid population. Out of the couple of species, Longipedia weberi found to be prevalent than Longipedia coronate in the family.

Pletidiidae possess single representation, Clytemnestra scutellata for its share $0.9 \%$ of total Harpacticoid density. Metidae: A single species, Metis jousseaumei alone stood for this family and constituted $0.4 \%$ of overall counting. This species was not commonly observed during the study period.

In this suborder, less density was noticed during November and high density was marked during the month of April. Euterpina acutifrons was the plethoric species in all the months of study and scored its maximum density (43300 numbers $\mathrm{m}^{-3}$ ) during the month of April. The current results were in line with the results of Naz (2012) who found that E. acutifrons and Macrosetella gracilis were the dominant harpacticoids throughout the year. As per the results of Kartha (1959) harpacticoid copepod occurred throughout the year with slight variations in its abundance and blatant increase in its number during May-August. Prabu et al., (2015) reported that Euterpina acutifrons was dominant species in zooplankton at Rameswaram, Gulf of Mannar but their population density was 567 numbers $\mathrm{m}^{-3}$ which was very meagre while compare with the present population density. There was significant difference $(\mathrm{P}<0.05)$ observed in overall harpacticoida population density in different stations and during different months. The maximum population density of 60200 and 47900 numbers were noticed in Keelavaipar station and April month respectively.

\section{Cyclopoida}

In Cyclopoida entire population was represented by single family Oithonidae. Among the four species observed in this family Oithona brevicornis was the dominant species which comprises $79 \%$ of the overall Cyclopoid biomass. The population density of Cyclopoida was maximum in the month of April in Vembar station which was due to the abundance of Oithona brevicornis. During the entire period of study Oithona brevicornis was the dominant species which was followed by Oithona linearis. There was significant difference $(\mathrm{P}<0.05)$ noticed in overall population density of cyclopoida in different stations. The overall maximum density of 20000 numbers $\mathrm{m}^{-3}$ was observed in Vembar.

The present result is supported by Paffenhofer (1993), Gallienne and Robins (2001) who explains that the family Oithonidae is one of the most abundant group inhabiting in the coastal waters in worldwide. Similarly, Rashiba (2010) reported that only Oithonidae is represents the sub-order Cyclopoida from Bay of Bengal. Further, Ananthan et al., (2007) also recorded the dominance of Oithona sp in Cuddalore backwater. According to Vineetha et al., (2015), Oithona brevicornis comes under the family Oithonidae, exhibited higher abundance among the Cyclopoids in tropical estuaries of Cochin. Oithona sp. formed a major part of total population throughout the year at Gulf of Mannar and Palk Bay and exhibits peak in April month (Kartha 1959).

\section{Poecilostomatoida}

Corycaeidae: This is the dominant family contributed $96.9 \%$ of Poecilostomatoids. Among the four species belonging to this family Corycaeus crassiusculus was the rifest species which alone represents $93.2 \%$ of Poecilostomatoid counts. Oncaeidae: Oncaea 
venusta was the single species represented Oncaeidae by comprising $1.4 \%$ of total Poecilostomatoid biomass. Sapphirinidae: It bestowed $1.1 \%$ counts of total Poecilostomatoid density with two genus namely Copilia and Sapphirina in its account. Species coming under these two genus were uncommon. Bomolochidae: The only species recorded in this family was Bomolochus sp. which accounts very meagre count $(0.6 \%)$ of Poecilostomatoid population. The recorded maximum density during April was owing to the massive presence of Corycaeus crassiusculus and this species was found ample numbers during the entire session of study. The results of present study is in accord with Baliarsingh (2014) who described that Corycaeidae was dominant in Poecilostomatoida at off shore estuaries of east coast. In the similar line of the present result, Kartha (1959) witnessed the presence Corycoeus in fair numbers throughout the year at Gulf of Mannar and Palk Bay with minor peak in March. There was significant difference $(\mathrm{P}<0.05)$ noticed in the population density of poecilostomatoida in different stations and during different months. The overall maximum density of 22400 and 17300 numbers were recorded in Vembar station and April month respectively.

While probing the overall population density of copepods the dominant species stood in the following order: Euterpina acutifrons $(28.61 \%)>$ Acrocalanus gracilis $(17.68 \%)>$ Corycaeus crassiusculus $(12.33 \%)>$ Oithona brevicornis $(12.03 \%)>$ Temora turbinata $(4.25 \%)>$ Calanopia minor $(2.1 \%)$. The present result was more similar to the reports of earlier workers mainly on the species distribution and abundance of copepods. Jagadeesan (2013) conveyed that the overall results of dominant species analysis of copepods showed the species such as Acartia spinicauda, Euterpina acutifrons, Oncaea venusta, Pareucalanus attenuatus, Temora discaudata and Onychocorycaeus catus were predominant in the Gulf of Mannar. According to Godhandaraman (1994) the genera Acartia and Acrocalanus belonging to calanoids and Euterpina and Oithona, belonging to harpacticoids and cyclopoids, respectively were the dominant forms of copepods in Pichavaram. In Tuticorin coast, the commonly distributed genera of copepods were Calanopia, Paracalanus, Eucalanus, Acrocalanus, Acartia, Labidocera Centropages, Euterpina, Oithona, Corycaeus and Microsetell during the year 1973 and 1974 (Marichamy, 1979). Achunathankutty et al., (1998), revealed that Paracalanus, Acrocalanus, Oithona, Pseudodiaptomus, Acartia and Corycaeus were the common genus of copepods in Goa coast. Piontkovski et al., (2013) reported that the dominance of small-sized copepods of genus Oithona, Temora, Oncaea, Parvocalanus, Paracalanus, Microsetella, Acartia and some others were a typical feature of the plankton community dwelling in coastal waters of the Sea of Oman. The study of (Padmavati and Goswami, 1996) revealed that Paracalanus parvus, nauplii of Balanus balanoides and metanauplii of Calanus finmarchicus were abundant throughout the season.

\section{Station and month wise population density}

The copepod biomass ranged between 3800 numbers $\mathrm{m}^{-3}$ in December and 64,600 numbers $\mathrm{m}^{-3}$ in April respectively from station III and station II. In station I, the copepod density varies from 8,600 to 36,900 numbers $\mathrm{m}^{-3}$ with the lower and higher biomass noticed during October and March month respectively. In station II, the population density of copepod was ranged between 3,900 and 64,600 numbers $\mathrm{m}^{-3}$. The least copepod density was recorded in November and most density recorded in April. The population counts of copepods in station III found between 3,800 and 24,800 
numbers $\mathrm{m}^{-3}$. Minimum and maximum counts were observed during December and April month respectively. In station IV, the copepod biomass ranged from 5,000 to 22,500 numbers $\mathrm{m}^{-3}$ respectively in the month of November and April. There was significant difference $(\mathrm{P}<0.05)$ observed in calanoida, cyclopoida, harpacticoida and poecilostomatoida population in different stations and during different months.

In all the stations the copepod population density was found at its lowest degree between October and December (monsoon season) and peak in the population was recorded during March and April (summer). This low and high density period has positively correlated with temperature and salinity. Accordingly peak in copepod density was noticed when there was a high range of temperature and salinity. Copepod population density does not show any positive correlation with $\mathrm{pH}$ and dissolved oxygen during the study period.

Supporting to the present study, Santhanam et al., (2012) found primary peak in copepod population during April and May in Velar estuary. Similar result was also reported by Santhanam and Perumal (2003) from the same area. In the similar line, Marichamy (1979) reported that higher population of copepods was observed during April and May and prominent fall in the quantity in copepods was noticed during September-November at Tuticorin. According to Godhandaraman (1994), the maximum and minimum numbers of copepods were found in May and September, respectively in Pichavaram mangrove waters. Maximum numerical counts of copepod population have been reported when the temperature and salinity were high in the environment (Rajasegar, 1998). In the Cooum and Adyar estuarine waters the total abundance of copepods were highest in summer and pre-monsoon than the other seasons as frequently observed in most of the coastal and estuarine waters (Goswami, 1982). According to Padmavati and Goswami (1996), nearly all the species of copepods were observed during summer followed by pre-monsoon and post-monsoon seasons. This is in line with present study.

High density of copepod in summer season might be due to favourable salinity, temperature as well as phytoplankton abundance (Padmavati and Goswami, 1996; Godhantaraman, 2001; Santhanam and Perumal, 2003; Prabu et al., 2005). The low density of copepod population during monsoon was owing to low availability of feed, low salinity and temperature as well as the water column was markedly stratified to a large extent because of high rainfall (Godhantaraman, 1994; Padmavathi and Goswami, 1996; Prasad, 2003; Nilssen and waervagen, 2003). And many copepod species disappeared during monsoon and species composition also changed great extent because most of them are stenohaline (Eswari and Ramanibai, 2004). Smaller diversity and abundance during monsoon season is attributed to their less tolerance and growth rate with low salinity and oxygen consumption.

When salinity is elevated, the copepod population will also be exalted in numbers and in such instances other factors like dissolved oxygen and $\mathrm{pH}$ will have less impact on copepod population (Padmavati and Goswami, 1996). In the same line Santhanam and Perumal (2003) found that salinity have positive correlation with population density of $A$. spinicauda and $O$. similis at Vellar estuary. Similar to recent result, Mitra et al., (1990) recorded higher population density and more number of copepod species at Mandarmani creek of West Bengal when the salinity was high and relatively stable. 
The present study has generated a baseline data on the abundance and distribution of copepod species and its diversity in the offshore region of Gulf of Mannar in different seasons. This present information will give a insight on the copepod species diversity in offshore region for future research which is generally scarce for offshore regions in Gulf of Mannar coast.

\section{Acknowledgement}

The authors are thankful to Dean, Fisheries College and Research Institute, Tuticorin, India for carry out this research work.

\section{References}

Achuthankutty, C.T., Ramaiah, N., and Padmavati, G. 1998. Zooplankton variability and copepod assemblage in the coastal and estuarine waters of Goa along the central-west coast of India. In: Pierrot-Bults, A.C., and van der S. Spoel (Ed.), Pelagic Biogeography ICoPB II. UNESCO, The Netherlands pp 1-11.

Ananthan, G., Sampath-Kumar, P. Soundarapandian, P., and Kannan, L. 2007. Distribution of zooplankton in Uppanar backwaters of Cuddalore, Southeast coast of India. In: Director, Zoological Survey of India (Ed.), National symposium on conservation and valuation of marine biodiversity. Zoological Survey of India, India, pp 17.

Asha, P.S., and Diwakar, R. 2007. Hydrobiology of the inshore waters off Tuticorin in the Gulf. J. Mar. Biol. Ass. India 49, 7-11.

Balasubramanian, R., and Kannan, L. 2005. Physico-chemical characteristics of the coral reef environments of the Gulf of Mannar Biosphere Reserve, India. Int. J. Ecol. Environ. Sci. 3, 265-271.
Baliarsingh, S.K., Srichandan, S., Sahu B.K., Sahu, K.C., Lotliker, A.A., and Kumar, T.S. 2014. Zooplankton community distribution along offshore transects of some Indian estuaries of east coast. Ind. J. Geo-Mar. Sci. 43, 1781-1791 .

Beyst, B., Buysse, D., Dewicke, A., and Mees, J. 2001. Surf zone hyperbenthos of Belgian sandy beaches: Seasonal patterns. Estuarine, Coastal and Shelf Sci. 53, 877-895.

Buddemeier, R.W., and Hopley, D. 1998. Turn- ons and turn - offs: causes and mechanisms of the initiation and termination of coral reef growth. In: Choat, J.H., Barnes, D., Borowitzka, M.A., Coll, J.C., Davies, P.J., Flood, P., Hatcher, B.G., Hopley, D., Hutchings, P.A., Kinsey, D., Orme, G.R., Pichon, M., Sale, P.F., Sammarco, P., Wallace, C.C., Wilkinson, C., Wolanski, E., and Bellwood, O., (Ed.), Proceedings in Sixth International Coral Reef Congress. Australia: International Society for Reef Studies, pp. 253-261.

De Puelles, M.L.F., Gra's, D., and Herna'ndez-Leo'n, S. 2003. Annual cycle of zooplankton biomass, abundance and species composition in the neritic area of the Balearic Sea, western Mediterranean. Mar. Ecol. 24, 123-139.

Easterson, D.C.V., and Victor, A.C.C. 1998. Report on initial environmental examination (IEE) of Sethusamudram Ship Canal Project: Living resources. Central Marine Fisheries Research Institute, Cochin, India.

Eswari, Y.N.K., and Ramanibai, R. 2004. Estuarine copepod abundance and diversity in relation to environmental variables, southeast coast of India. J. Mar. Biol. Ass. India, 46, 10-20.

Fernandes, V., and Ramaiah, N. 2009. Mesozooplankton community in the Bay of Bengal (India): spatial 
variability during the summer monsoon, Aqua. Ecol. 43, 951-963.

Gallienne, C.P., and Robins, D.B. 2001. Is Oithona the most important copepod in the world's oceans?. J. Plankton Res. 23, 1421-1432.

Gaudy, R., Cervetto, G., and Pagano, M. 2000. Comparison of the metabolism of Acartia clausi and A. tonsa: influence of temperature and salinity. J. Exp. Mar. Biol. Ecol. 247, 51-65.

Gleason, H.A. 1922. On the relation between species and area. Ecol. 3, 155-162.

Godhantaraman, N. 1994. Studied the delayed hydrobiological account of 35 species of rotifers belonging to 17 genera in Pichavaram mangroves (South India). Ciencias Marinas 20, 371-391.

Godhantaraman, N. 2001. Seasonal variations in taxonomic composition, abundance and food web relationship of microzooplankton in estuarine and mangrove waters, Parangipettai region, Southeast coast of India. Ind. J. Mar. Sci. 30, 151-160.

Gommbre. 1997. Gulf of Mannar Marine Biosphere Reserve Report. Ramanathapuram, India: Tamilnadu Forest Department.

Gopinathan, C.P., and Rodrigo, J.X. 1991. Investigations on primary production and related parameters in the inshore waters of Tuticorin. J. Mar. Biol. Ass. India, 33, 33-39.

Goswami, S.C. 1982. Distribution and diversity of copepods in the MandoviZuari estuarine system, Goa. Ind. J. Mar. Sci. 11, 292-295.

Jagadeesan, L., Jyothibabu, R., Anjusha, A., Mohan, A.P., Madhu, N.V., Muraleedharan, K.R., and Sudheesh, K. 2013. Ocean currents structuring the mesozooplankton in the Gulf of Mannar and the Palk Bay, southeast coast of India. Prog. Oceanogr 110, 27-48.
Kannan, L. 1996. Report on the biodiversity of microbial flora (bacteria and phytoplankton) of the coral reef of the Gulf of Mannar. Submitted to Ministry of Environment and Forest, pp. 76

Kannan, L., Kathiresan, K., and Purushothaman, A. 1998. Biodiversity of microbial flora (bacteria and phytoplankton) of the coral reefs of the Gulf of Mannar. In: Maikhuri, R.K., Rao, K.S., and Rai, R.K. (Ed.), Biosphere Reserves and Management in India. Himavikas occasional publication No. 12, Almora, India, pp 207-220.

Kartha, 1959. A study of the copepods op the inshore waters of Palk bay and Gulf of Mannar. Ind. J. Fish. 6, 256 - 267.

Kasturirangan, L.R. 1963. A key for the identification of the more common planktonic Copepoda of the Indian coastal waters. In: Panikkar, N.K. (Ed.), Publication No. 2 of Indian National Committee on Oceanic Research. New Delhi, India: The Council of Scientific \& Industrial Research, pp 1- 87.

Krishnaswami, S. 1952. Some new species of copepods from the Madas coast. Rec. Ind. Mus. 49, 321-336.

Krishnaswami, S. 1953. Pelagic Copepoda of the Madras coast. J. Mad. Univ. 23b, 61-75.

Kumar, J.S.Y., and Geetha, S. 2012. Seasonal changes of hydrographic properties in sea water of coral reef islands, Gulf of Mannar, India. Int. J. Plant Ani. Environ. Sci. 2, 135-159.

Leandro, S.M., Morgado, F., Pereira, F., and Queiroga, H. 2007. Temporal changes of abundance, biomass and production of copepod community in a shallow temperate estuary (Ria de Aveiro, Portugal). Estuarine, Coastal and Shelf Sci. 74, 215-222.

Madhupratap, M. 1979. Distribution, community structure and species 
succession of copepods from Cochin backwaters. Ind. J. Mar. Sci. 8, 1-8.

Madhupratap, M. 1999. Free living copepods of the Arabian Sea: distributions and research perspectives. Ind. J. Mar. Sci. 28, 146-149.

Marichamy, R., and Panigrahy, R.C. 1999. Zooplankton ecology of the Bahuda estuary (Orissa), east coast of India. Ind. J. Mar. Sci. 28, 297-301.

Mitra, A., Patra, K.C., and Panigraphy, R.C. 1990. Seasonal variations of some hydrographical parameters in a tidal creek opening into the Bay of Bengal. Mahasagar. Bull. Nat. Inst. Oceanogr. 23, 55-62.

Naz, F., Qureshi, N.A., and Saher, N. 2012. Temporal and spatial variations in the species composition, distribution and abundance of copepods in mangrove creek area along the Karachi coast, Pakistan. Ind. J. Geo-Mar. Sci. 41, 6169. .

Padmavathi, G., and Goswami, C. 1996. Zooplankton ecology in the MandoviZuari estuarine system of Goa, West coast of India. Ind. J. Mar. Sci. 25, 268273.

Paffenhofer, G.A. 1993. On the ecology of marine cyclopoid copepods (Crustacea, Copepoda). J. Plankton Res. 15, 37-55.

Paramasivam, S., and Kannan, L. (2005). Physico-chemical characteristics of Muthupettai mangrove environment, Southeast coast of India. Int. J. Ecol. Environ. Sci. 31, 273-278.

Parsons, T.R., Yoshiaki, M., and Carol, M.L. 1984. A Manual of chemical and biological methods for seawater analysis. Pergamon Press, Oxford, U.K..

Perumal, V.N., Rajkumar, M., Perumal, P., and Rajasekar T.K. (2009). Seasonal variations of plankton diversity in the Kaduviyar estuary, Nagapattnam, South East Coast of India. J. Environ. Biol. 30, 1035-1046.
Pielou, E.C. 1966. The measurement of diversity in different types of biological collections. J. Theoretical Biol. 13, 131144.

Pillai, H.U., Jayalakshmy, K.V., Biju, A., Jayalakshmi, K.J., Paulinose, V.T., Devi, C.B., Nair, V.R., Revichandran, C., Menon, N.R., Achuthankutty, C.T., and Panampunnayil, S.U. 2014. A comparative study on mesozooplankton abundance and diversity between a protected and an unprotected coastal area of Andaman Islands. Environ. Monit. Assess. 186, 3305-3319.

Pillai, P.P. 1971. Studies on estuarine copepods of India. J. Mar. Biol. Ass. India 13, 162-172.

Piontkovski, S.A., Al-Maawali, A., AlMantheri, W., Al-Hashmi, K., and Popova, E. 2013. Zooplankton of Oman coastal waters. Agri. Mar. Sci. 18, 3750.

Prabhahar, C., Saleshrani, K., and Enbarasan, R. (2011). Studies on the ecology and distribution of zooplankton biomass in kadalur coastal zone, Tamil nadu, India. Curr. Bot. 2, 01-04.

Prabu, V.A., Harikumar, S., and Manimaran, K. 2015. Seasonal variation of plankton diversity in southeast coast of India. Int. J. Curr. Trends Res. 4, 46-53.

Prabu, V.A., Perumal, P., and Rajkumar, M. 2005. Diversity of microzooplankton in Parangipettai coastal waters, southeast coast of India. J. Mar. Biol. Ass. India 47, 14-19.

Prasad, N.V. 2003. Diversity and richness of zooplankton in Coringa mangrove ecosystem: Decadal changes. J. Aqua. Biol. 18:41-46.

Prasad, R.R. 1954. The characteristics of plankton at an inshore station in the Gulf of Mannar near Mandapam. Ind. J. Fish. 1, 1-36.

Prasad, R.R. 1957. Seasonal variations in the surface temperature of sea-water at 
Mandapam from January 1950 to December 1954. Ind. J. Fish. 4, 20-31.

Rajasegar, M. 1998. Environmental inventory on Vellar estuary (Southeast coast of India) in relation to shrimp farming. Ph.D. Thesis, Annamalai University, India.

Ramaiah, N., and Nair, V. 1997. Distribution and abundance of copepods in the pollution gradient zones of Bombay Harbour - Thane creek- Basin creek, west coast of India. Ind. J. Mar. Sci. 26, 20-25.

Rashiba, A.P. 2010. Studies on Copepods from the EEZ of India-Bay of Bengal and Andaman Sea, Ph.D. Thesis, Cochin University of Science and Technology, India.

Raymont, J.E.G. 1980. Plankton and Productivity in the Oceans, Vol. 1: Phytoplankton. Pergamon Press, Oxford, U.K..

Sahu, G., Mohanty, A.K., Singhasamanta, B., Mahapatra, D., Panigrahy, R.C., Satpathy, K.K., and Sahu, B.K. 2010. Zooplankton Diversity in the Nearshore waters of Bay of Bengal, Off Rushikulya Estuary. J. Environ. Sci. 4, 61-85.

Sampey, A., Mckinnon, A.D., Meekan, M.G., and McCormick, M.I. 2007. Glimpse into guts: Overview of the feeding of larvae of tropical shore fishes. Mar. Ecol. Prog. Ser. 339, 243-257.

Santhanam, P., and Perumal, P. 2003. Diversity of zooplankton in Parangipettai coastal waters, southeast coast of India. J. Mar. Biol. Ass. India 45, 144-151.

Santhanam, P., Perumal, P., Ananth, S., and Devi, A.S. 2012. Copepod population in Vellar estuary, Parangipettai coast in relation to environmental conditions. J. Environ. Biol. 33, 1003-10.

Santhanam, R., and Srinivasan, A. 1994. A Manual of Marine Zooplankton. Oxford and IBH Publishing Co, New Delhi, India.

Saravanakumar, A., Rajkumar, M., Thivakaran, G.A., and Serebiah, J.S. 2008. Abundance and seasonal variations of phytoplankton in the creek waters of western mangrove of KatchGujarat. J. Environ. Biol. 29, 271-274.

Sarkar, S.K., Singh, B.N., and Choudhury. R. 1986. Seasonal distribution of copepods in the Hooghly estuary, Northern Bay of Bengal. Ind. J. Mar. Sci. 15, 177-180.

Sewell, R.B.S. 1914. Notes on the surface copepoda of the Gulf of Mannar. Spolia Zeylanica, 9, 191- 262.

Sewell, R.B.S. 1929a. Geographic and oceanographic research in Indian waters. V. The temperature and salinity of the surface waters of the Bay of Bengal and Andaman Sea with reference to Laccadive Sea. Memories of Asiatic Soc. Bengal 9, 207- 355.

Sewell, R.B.S. 1929b. The copepoda of Indian seas. Biotech Books, Delhi, India.

Shannon, C.E., and Wiener, W. 1949. The mathematical theory of communication. Urbana, University of Illionis press, U.S.A.

Shanthi, M., and Ramanibai, R. 2011. Studies on Copepods from Chennai Coast (Cooum and Adyar), Bay of Bengal During the Cruise. Curr. Res. J. Biol. Sci. 3, 132-136.

Sherr, E., and Sherr, B. 2009. Understanding roles of microbes in marine pelagic food webs: a brief history. In: Kirchman, D.L. (Ed.), Microbial Ecology of the Oceans, $2^{\text {nd }}$ Edition. Wiley, New York, pp 27-44.

Sivaleela, G., and Venkataraman, K. 2014. Diversity and distribution of harpacticoid copepods from Tamilnadu coast, India. Rec. Zool. Surv. India 114, $1-11$. 
Srichandan, S., Sahu, B.K., Panda, R., Baliarsingh, S.K., Sahu, K.C., and Panigrahy, R.C. 2015. Zooplankton distribution in coastal water of the North-Western Bay of Bengal, off Rushikulya estuary, east coast of India. Ind. J. Geo-Mar. Sci. 44, 546-561.

Sridhar, R., Thangaraju, T., Kumar, S.S., and Kannan, L. 2006. Water quality and phytoplankton characteristics in the Palk Bay, Southeast coast of India during pre - tsunami period. J. Environ. Biol. 28, $561-566$.

Subramanian, S.K., and Kannan. L. 1998. Environmental parameters of Indian marine biosphere reserve of Tuticorin in Gulf of Mannar. J. Seaweed Res. Utiliz. 20, 85-90.

Sugumaran, J. 2016. Influence of Seasons on copepods of Agniyar Estuary, Palk Strait, Tamil Nadu, India. Int. J. Zool. Appl. Biosci. 1, 40-45.

Sujatha, M., and Panigrahy, R.C. 1996. Copepods of Bahuda estuary (Orissa), east coast of India. Ind. J. Mari. Sci., 25, 98-102.

Timofeev, S.F. 2000. Ecology of the marine zooplankton (in Russian). Murmansk, Russia: Murmansk State Pedagogical Institute Press.
Ummerkutty, A.N.P. 1967a. Studies on Indian copepods. Observations on the diurnal vertical movements of planktonic copepods in the Gulf of Mannar, Bom. Nat. Hist. Soc. 63, 332 - 343.

Ummerkutty, A.N.P. 1967b. Observations on the breeding and seasonal abundance of ten species of planktonic copepods of the Gulf of Mannar. In: Pillai, N.K. (Ed.), Proceedings of the Symposium on Crustacea, Part 2. Ernakulam, India: Marine Biological Association of India, pp 685 - 697.

Ummerkutty, A.N.P. 1961. Studies on Indian copepods: 5. On eleven new species of marine cyclopoid copepods from the south-east coast of India. J. Mar. Biol. Ass. India 3, 19-69.

Venkataraman, K., Raghunathan, C., Raghuraman, R., and Sreeraj C.R. 2012. Coastal and Marine Biodiversity of India. Kolkata, India: Zoological Survey of India.

Vineetha, G., Madhu, N.V., Kusum, K.K., and Sooria, P.M. 2015. Seasonal dynamics of the copepod community in a tropical monsoonal estuary and the role of sex ratio in their abundance pattern. Zool. Stud. 54, 1-19.

\section{How to cite this article:}

Kavitha, M., P. Padmavathy, A. Srinivasan, P. Jawahar, L. Ranjith and Linga Prabu, D. 2018. Copepod Abundance and Diversity from Offshore Region of Tuticorin, South East Coast of India. Int.J.Curr.Microbiol.App.Sci. 7(04): 2767-2792.

doi: https://doi.org/10.20546/ijcmas.2018.704.316 